Article

\title{
Degradation and Dependence Analysis of a Lithium-Ion Battery Pack in the Unbalanced State
}

\author{
Xiaohong Wang ${ }^{1}$, Shixiang $\mathrm{Li}^{1}$, Lizhi Wang ${ }^{2,3, *}$, Yaning Sun ${ }^{1}$ and Zhongxing Wang ${ }^{4}$ \\ 1 School of Reliability and Systems Engineering, Beihang University, Beijing 100191, China; \\ wxhong@buaa.edu.cn (X.W.); lishixiang@buaa.edu.cn (S.L.); sunyaning_1206@163.com (Y.S.) \\ 2 Institute of Unmanned System, Beihang University, Beijing 100191, China \\ 3 Key Laboratory of Advanced Technology of Intelligent Unmanned Flight System of Ministry of Industry and \\ Information Technology, Beijing 100191, China \\ 4 Institute of Geology and Geophysics, Chinese Academy of Sciences, Beijing 100029, China; \\ zxwang@mail.igcas.ac.cn \\ * Correspondence: wanglizhi@buaa.edu.cn; Tel.: +86-138-1043-8269
}

Received: 17 October 2020; Accepted: 10 November 2020; Published: 13 November 2020

check for updates

\begin{abstract}
Lithium-ion batteries are widely used in the energy field due to their high efficiency and clean characteristics. They provide more possibilities for electric vehicles, drones, and other applications, and they can provide the higher requirements necessary for the reliability of battery pack systems. However, it is easy for a battery pack to be unbalanced because of the dependence between the cells. The unbalanced state will make the degradation process more complex and cause abnormal discharge parameters, which brings challenges in the analysis of the state of health $(\mathrm{SOH})$ of battery packs. In order to study the degradation process in the unbalanced condition, in this study, a degradation test of four different configurations of battery packs was designed and implemented, and the degradation process was primarily studied from the perspective of dependence. First, the degradation characteristics and dependency degree of different configurations of the unbalanced state were discussed. Second, a hypothesis test and a linear regression analysis were used to analyze the degradation process and the acceleration effect of a battery pack in the unbalanced state. Finally, partial least squares regression was used to establish the dependence model of battery packs in the unbalanced state. A high regression coefficient $\left(\mathrm{R}^{2}>0.9\right)$ and low $p$-value $<0.0001$ indicated that the correlation of the degradation process was effectively quantified. The results provide a reference for optimizing a consistent design of battery packs and managing the $\mathrm{SOH}$ of battery packs.
\end{abstract}

Keywords: lithium-ion battery packs; unbalanced state; degradation dependence

\section{Introduction}

Lithium-ion batteries have attracted great interest in recent years due to their high specific energies, long cycle lives, and wide operating temperature ranges. Electric vehicles [1], hybrid ships [2], and unmanned aerial vehicles (UAVs) [3] powered by lithium-ion batteries have also been widely used. Therefore, the safety and reliability of lithium-ion batteries play an important role in the operation of equipment and the health of a system. Because of the low voltage of the lithium cells, they must work as a battery pack in power supply applications. Ideally, the cells will remain consistent, and their degradation processes will be regular and controlled. In reality, it is difficult to maintain good consistency between single cells because of the initial difference and environmental stresses (temperature, humidity, vibration and other external factors during use). In this case, a pack can easily enter an unbalanced state due to the dependence between the cells, which causes accelerated degradation and other consequences. Therefore, the determinant of the performance and reliability of a power supply system is not only the cells but also the dependence of the packs. 
The unbalanced state refers to a situation in which the high level of non-uniformed operational states of the components would speed up the failure process of an entire system [4]. As a typical performance balancing system, the consistency of lithium-ion packs has always been a matter of concern [5-8]. Due to manufacturing tolerances and environmental stresses during use, there are typically performance differences between individual cells [9]. This, in conjunction with the strong dependence of the cells, will cause an unbalancing effect for a battery pack, such as over-current and over-discharge [10]. Recently, some methods have been developed to alleviate the unbalance of battery packs, mainly divided into the active balance method and passive balance method [11-13]. The active balance method uses external circuits to actively transport energy from cells with higher SOC(State of charge) to cells with lower SOC by using a switched capacitor as an intermediate repository. It ensures that all energy stored in the battery can be fully utilized, thereby maximizing the available capacity of the battery. The passive balance method enables the battery with excess energy to exhaust the excess energy as heat through the dissipation bypass until the charge matches that of the lower cells in the pack or charge reference. However, the active balance method requires more additional components, increasing the cost and unreliability, and the battery needs to be balanced for a long time. The passive balance method will cause the battery energy to be dissipated as heat, resulting in lower energy efficiency, and cannot be used in lithium-based batteries due to the high risk of explosion. Most of these methods cure the symptoms but do not focus on the actual degradation process [14]. The dependence of lithium-ion batteries has been confirmed in a previous study [10]. In the lithium-ion battery pack balance system, the degradation processes of each cell in the battery pack affect each other. Ideally, the dependence effect is not significant, and it will not exert much influence on the use and analysis of the battery pack. However, as the unbalanced state occurs and accumulates easily, the reliability of the battery pack is greatly reduced, and the interaction between the cells makes it difficult to clarify the degradation process, which brings great difficulties to the balance strategy and health assessment of the battery pack. In order to solve the unbalance problem further, it is meaningful to study the degradation law and dependent effect in the unbalanced state.

Previous research has shown that initial variations in production and environment stresses in use are the primary causes of battery pack unbalance $[9,10,14-16]$. The unbalanced effect of a battery pack is mainly revealed in the uneven distribution of characteristic parameters of the charge-discharge process. This includes over-current and over-discharge caused by an uneven current and voltage distribution, high temperatures caused by a difference in the internal resistance, and the circulating current caused by a difference in the open-circuit voltage [17-19]. Specifically, in a series circuit, Stoican [20] and Aizpuru [21] pointed out that an uneven distribution of the voltage would cause a difference in the open-circuit voltage between the cells. This would form a reverse voltage, and the difference of the internal resistance would make the temperature increase significantly. They also pointed out that the connection method of an external circuit was one of the primary causes of the unbalanced state. Compared with a series circuit, the unbalance of a parallel circuit is reflected more in the uneven current distribution. Chang [22] and Shi [23] used an equivalent circuit model to study the current distribution mechanism of parallel circuits and the unbalanced intensity caused by different degradation degrees. They found that the unbalanced effect would exacerbate with an increase in the cell's differences, and they proposed to reduce the deviation of the product of the resistance and capacity to relieve the unbalance effectively. Zhang [24] also studied the risk of current unbalance in a parallel circuit, and they found unbalanced effects including the over-discharge and circulating current. However, these studies have primarily focused on the variation trend of the characteristic parameters of a battery pack in the unbalanced state, and there was not much focus on the dependent degradation mechanism of a battery pack for the unbalanced condition. In addition, the research object has primarily been the single configuration, and the unbalanced effect on a series-parallel combination needs to be examined.

Based on the above discussion, building a model of battery pack degradation and quantitatively analyzing the dependence between cells is important for studying the unbalanced state. There have been 
some recent studies which have presented results of the battery pack modeling method [25-28]. Most of the research was focused on the various performance indicators based on the cell-to-cell variation, and a battery pack variation quantitative model was built to evaluate performance. In contrast, there have been few studies on the degree and difference of dependence between cells. The traditional modeling method for analyzing degradation dependency is the statistical dependence analysis presented by Copula [29]. However, due to the complexity of the algorithm, the difficulty of high-dimensional expansion, and the need for an accurate component distribution function, it was difficult to conduct this analysis for the small sample test data utilized in this research [30]. Partial least squares regression (PLSR) considers the degree of influence of a sample population on a predicted value, and it fully considers the degree of influence of the combined effect of individual factors on the predicted value. Its regression factor extraction focuses on maximizing factors and covariances, and the factors can contain more information about the system of independent variables in order to maximize the ability to interpret the dependent variables [31]. For a battery pack, the PLSR method can fully consider the correlation between the cells and the battery pack, as well as analyze the degree of influence of every single cell in the battery pack, eliminating the collinearity between the data to ensure the accuracy of the model.

In summary, in this study, a battery pack unbalanced cycle degradation test was designed and implemented in four configurations. The unbalanced state was formed by implanting degraded batteries, and the discharge capacity was used as the health status index of the battery pack [32]. First, based on the test data, the unbalanced effect of the battery pack was analyzed based on the profile of cyclic charging and discharging. Second, a hypothesis test and linear regression were used for the quantitative analysis and modeling of the degradation process. Finally, the PLSR was used to model the dependence of the battery pack. The results could provide a theoretical basis for a consistent design of a battery pack and the optimization of balance strategy for a battery pack.

The rest of this paper is organized as follows. Section 2 introduces the life cycle tests of battery packs during unbalanced conditions. Section 3 presents the test results of battery aging in detail and describes the analysis of the dependent degradation relationship. In Section 4, the conclusions of this research are summarized $[33,34]$.

\section{Experimental Methods}

To provide the necessary data for the difference analysis and the modeling of the degradation process of batteries in the unbalanced condition, degradation tests of lithium-ion battery packs were designed and conducted for the unbalanced condition.

\subsection{Test Equipment}

The test cells were 18,650 cylindrical lithium-ion batteries manufactured by Samsung SDI. The parameters are shown in Table 1.

Table 1. Nominal specifications of a battery.

\begin{tabular}{cc}
\hline Item & Specification \\
\hline Typical Capacity & $2150 \mathrm{mAh}$ \\
Minimum Capacity & $2050 \mathrm{mAh}$ \\
Charging Voltage & $4.2 \mathrm{~V} \pm 0.05 \mathrm{~V}$ \\
Nominal Voltage & $3.62 \mathrm{~V}$ \\
Charging Method & Constant voltage with limited current \\
Charging Current & Standard charge: $1075 \mathrm{~mA}$ \\
& Rapid charge: $2150 \mathrm{~mA}$ \\
Charging Time & Standard charge: $3 \mathrm{~h}$ \\
& Rapid charge: $2.5 \mathrm{~h}$ \\
\hline
\end{tabular}


Table 1. Cont.

\begin{tabular}{cc}
\hline Item & Specification \\
\hline Max. Charge Current & $2150 \mathrm{~mA}$ \\
Max. Discharge Current & $10 \mathrm{~A}($ Continuous discharge $)$ \\
Discharge Cut-Off Voltage & $2.75 \mathrm{~V}$ \\
Cell Weight & $44.5 \mathrm{~g}$ max. \\
Cell Dimension & Diameter $(\max ): \Phi 18.40 \mathrm{~mm}$ \\
& Height: $65 \mathrm{~mm}$ max. \\
Operating Temperature & Charge: 0 to $45^{\circ} \mathrm{C}-10$ to $0{ }^{\circ} \mathrm{C}($ Charging voltage: $4.10 \mathrm{~V} /$ Cell, \\
Charging Current: Under $0.5 \mathrm{C})(2 *)$ \\
Storage Temperature & Discharge: -20 to $60^{\circ} \mathrm{C}$ \\
\end{tabular}

The relevant parameters and connection methods of the lithium-ion battery packs are detailed in the literature [10].

\subsection{Cycle Life Tests}

In order to ensure the comparability of the test results, it was necessary to ensure that:

1. The battery with no degradation treatment (referred to as the normal cell) had good initial consistency.

2. The battery that underwent the initial capacity degradation treatment (referred to as the degraded cell) had the same degree of degradation.

In this study, cells with good initial consistency were selected to form a battery pack. In the same production batch, twelve 18,650 lithium-ion batteries were randomly selected as the test batteries. The cells were discharged from the fully charged state at $1 / 20 \mathrm{C}$, and their initial discharge capacities were tested. The discharge capacity in this case was close to the maximum usable capacity of the battery. The optimal means of judging the consistency of the initial capacity is to check whether the capacity data conform to the normal distribution. The normality of the data can be verified by drawing the distribution histogram and p-p diagram of the capacity data. If the capacity obeys a normal distribution and the data are well distributed around the baseline, then the initial capacity can be considered to have good consistency. Figure 1 shows the initial capacity histogram and the normal probability plot of the cells. The data were distributed around the reference line. It can be seen that the initial capacity of the 12 cells could be modeled using a normal distribution. The fluctuation was small, and there were no abnormal values. The batteries had good initial consistency. Table 2 shows the initial capacity values of the test cells.

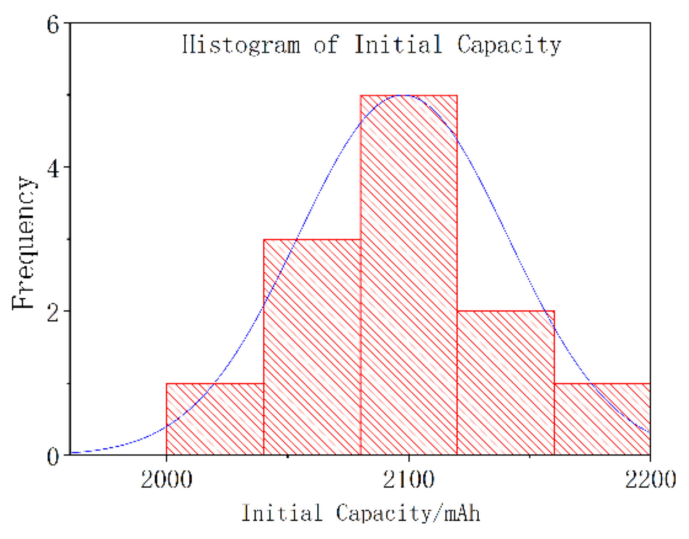

(a)

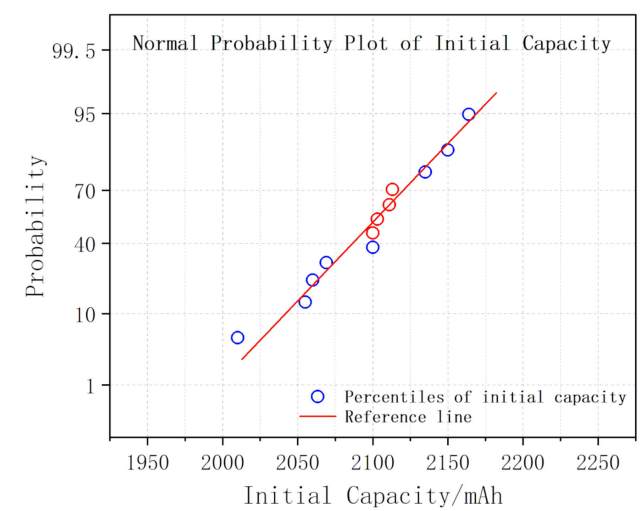

(b)

Figure 1. Cont. 


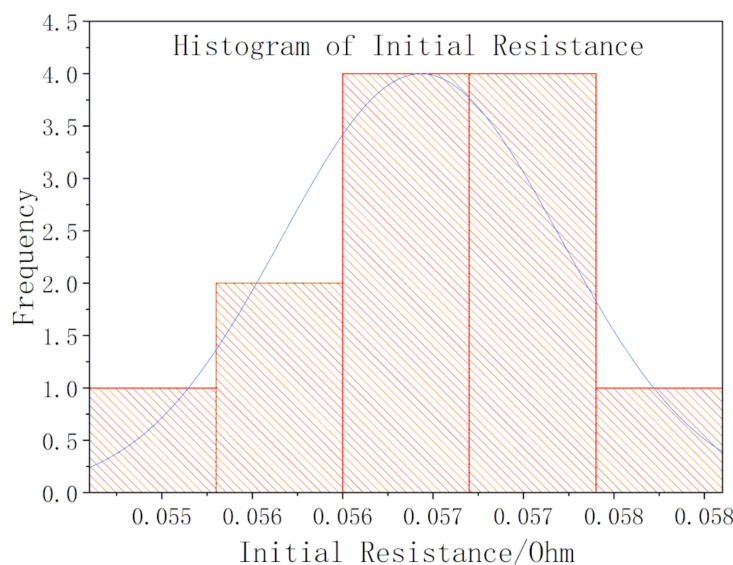

(c)

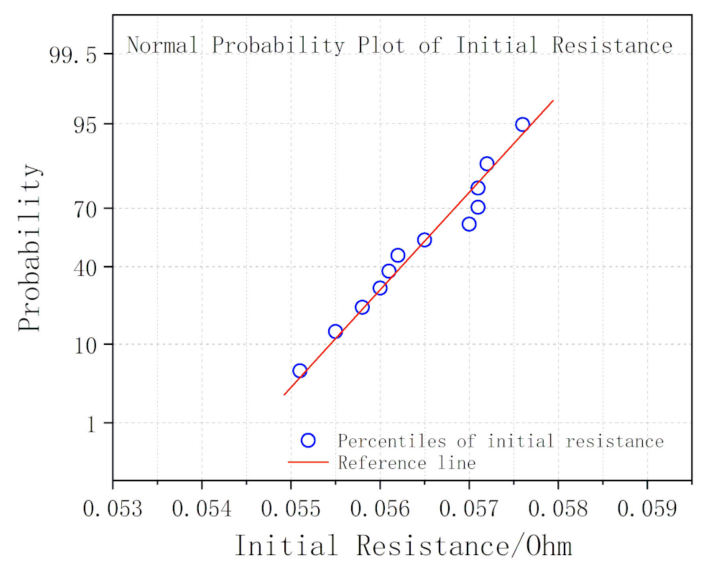

(d)

Figure 1. (a) Initial capacity distribution. (b) Normal probability plot of the initial capacities. (c) Initial resistance distribution. (d) Normal probability plot of the initial resistances.

Table 2. Initial capacities of the focal 12 cells.

\begin{tabular}{ccccccc}
\hline & Cell-1 & Cell-2 & Cell-3 & Cell-4 & Cell-5 & Cell-6 \\
\hline Initial capacity $(\mathrm{mAh})$ & $\mathbf{2 1 0 0}$ & 2095 & $\mathbf{2 1 0 3}$ & 2110 & $\mathbf{2 1 0 0}$ & 2090 \\
\hline & Cell-7 & Cell-8 & Cell-9 & Cell-10 & Cell-11 & Cell-12 \\
\hline Initial capacity $(\mathrm{mAh})$ & 2103 & 2104 & $\mathbf{2 1 0 1}$ & 2115 & 2099 & 2110 \\
\hline
\end{tabular}

After obtaining 12 cells with good initial consistency, Cell-1, Cell-3, Cell-5, and Cell-9 were selected for the degradation treatment to obtain the degraded cells that were used to implant a circuit. The cycle parameters of the degradation treatment had to be consistent with the degradation test parameters. The discharge capacity per cycle was measured. The degradation treatment was stopped after $95 \%$ of the initial capacity was reached. For the degraded cells, in order to ensure that the unbalanced states were at the same level in each battery pack, the capacity and internal resistance of the degraded batteries were also analyzed. The discharge capacity histogram and the probability plot of the treated degraded cells are shown in Figure 2 and the degraded discharge capacity values are shown in Table 3.

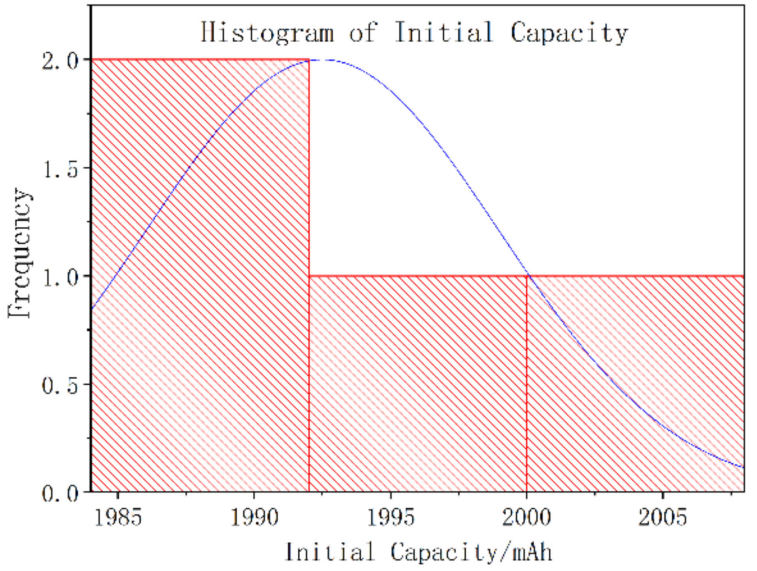

(a)

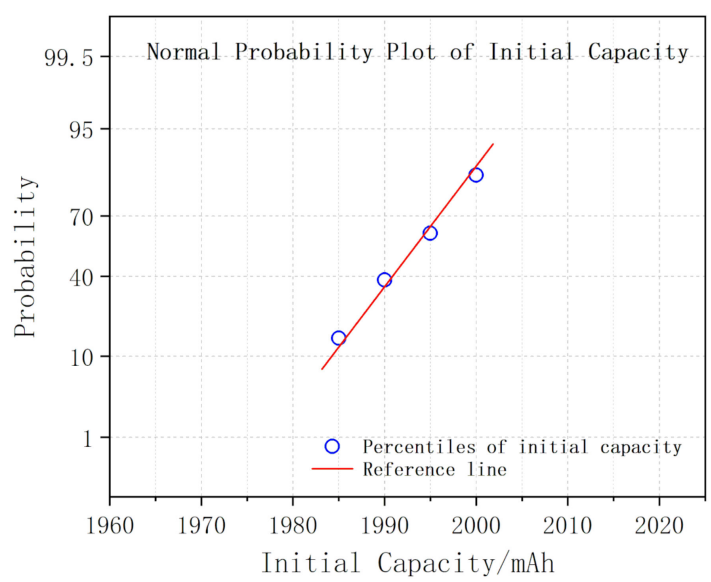

(b)

Figure 2. Cont. 


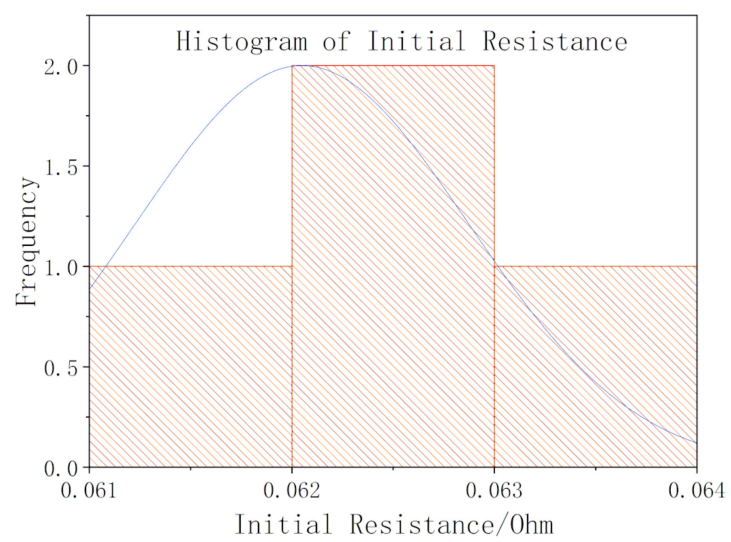

(c)

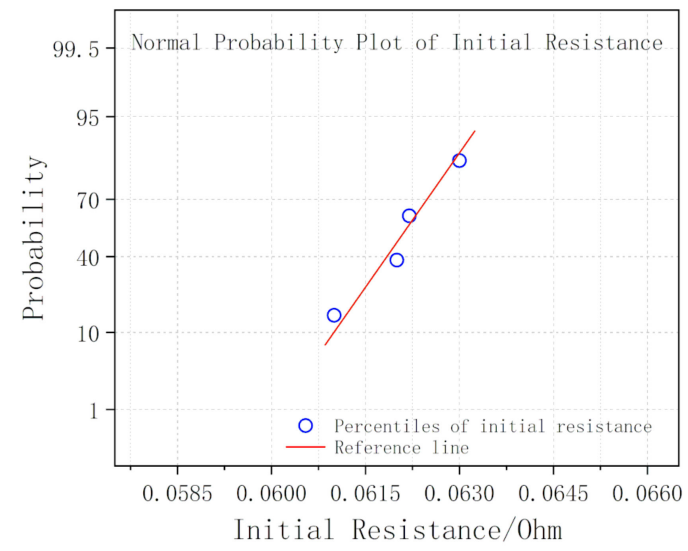

(d)

Figure 2. (a) Initial capacity distribution (degraded cells). (b) Normal probability plot of the initial capacity (degraded cells). (c) Initial resistance distribution (degraded cells). (d) Normal probability plot of the initial resistance (degraded cells).

Table 3. Initial capacity values of the degraded cells.

\begin{tabular}{lll}
\hline Cell & Initial Capacity (mAh) & Degraded Capacity (mAh) \\
\hline Cell-1 & 2100 & 1995 \\
Cell-3 & 2103 & 1997 \\
Cell-5 & 2100 & 1996 \\
Cell-9 & 2101 & 1995 \\
\hline
\end{tabular}

It can be seen that the degradation degree of the degraded battery was consistent, which ensured the high reliability of the test.

As shown in Figure 3, the battery pack unbalance degradation test was divided into four different configurations. Pack A: series, Pack B: parallel, Pack C: series and parallel, and Pack D: parallel and series. Each pack was implanted with a degraded cell. The black squares in the figure represent the degraded cells, and the white squares represent the normal cells.

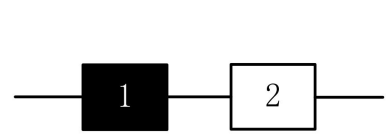

Pack A

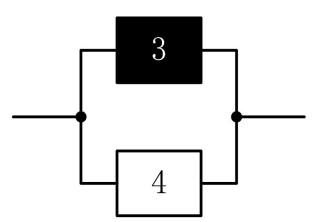

Pack B

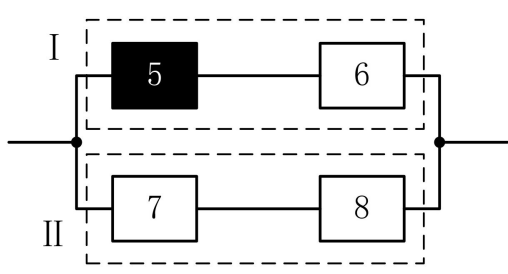

Pack C

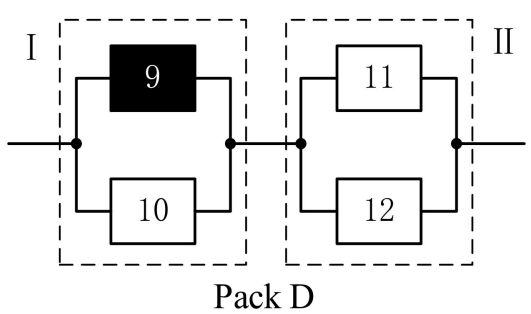

Pack D

Figure 3. Configurations of the four battery packs. 
The grouping situations and the cell numbers are shown in Table 4

Table 4. Test battery grouping and numbering.

\begin{tabular}{lll}
\hline Pack No. & Configuration & Cell No. \\
\hline Pack A & Series & Cell 1, 2 \\
Pack B & Parallel & Cell 3, 4 \\
Pack C & Series-parallel & Cell 5, 6, 7, 8 \\
Pack D & Parallel-series & Cell 9, 10, 11, 12 \\
\hline
\end{tabular}

During the degradation test, the batteries were placed in an optimal operating environment at $25 \pm 2{ }^{\circ} \mathrm{C}$. The effect of small temperature fluctuations on the test was then considered negligible. K-type thermocouples were placed in the same position on all battery surfaces to monitor the surface temperature of each cell in a battery pack. Similar to normal use, each charge-discharge cycle could be divided into five phases: (I) constant current charging (CC), (II) constant voltage charging (CV), (III) rest, (IV) constant current discharge (CC), and (V) rest. The test parameters for each charge and discharge cycle of each battery pack were same as in the literature [10].

The test parameters that were primarily recorded were the battery discharge capacity, the circulating voltage, the current, the cell temperature, and the ambient temperature.

\section{Results}

\subsection{Unbalance Analysis in the Charge-Discharge Cycle}

The parameter difference of each cell during the charge-discharge can directly reflect the dependence of each cell in the unbalanced state. In this research, a charge-discharge profile was used as an example to observe the difference between the typical characteristic parameters (current and voltage) of the cells in each stage of the charge-discharge cycle. As shown in Figure 4, the current value of the charging process was defined as positive, and the current value of the discharging process was negative.
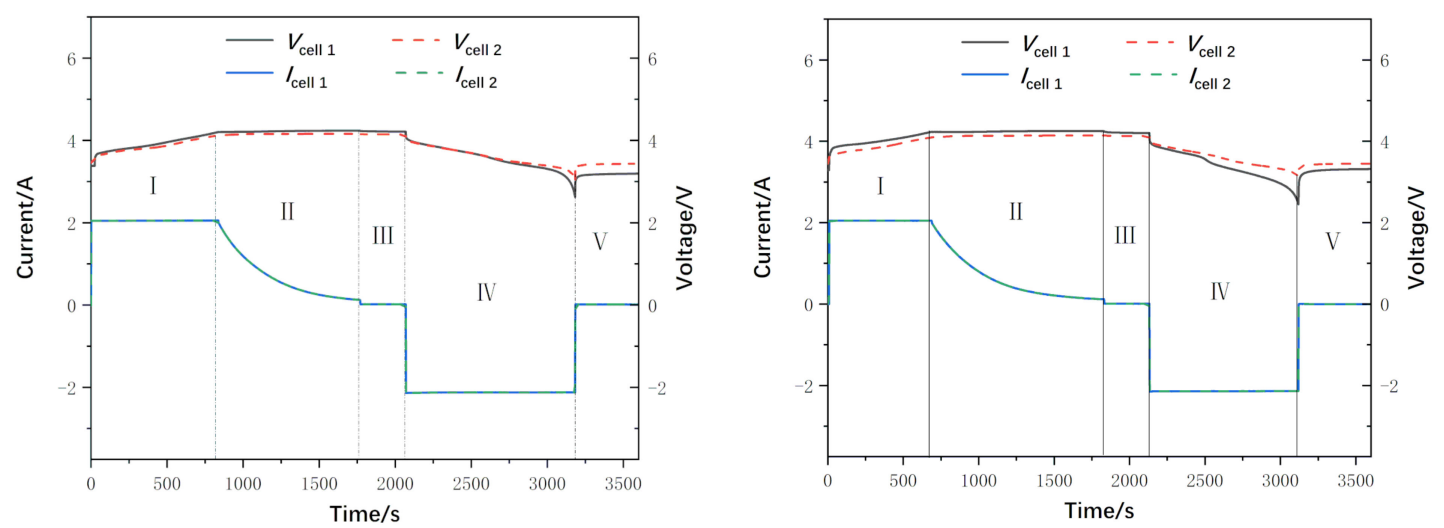

(a)

Figure 4. Cont. 

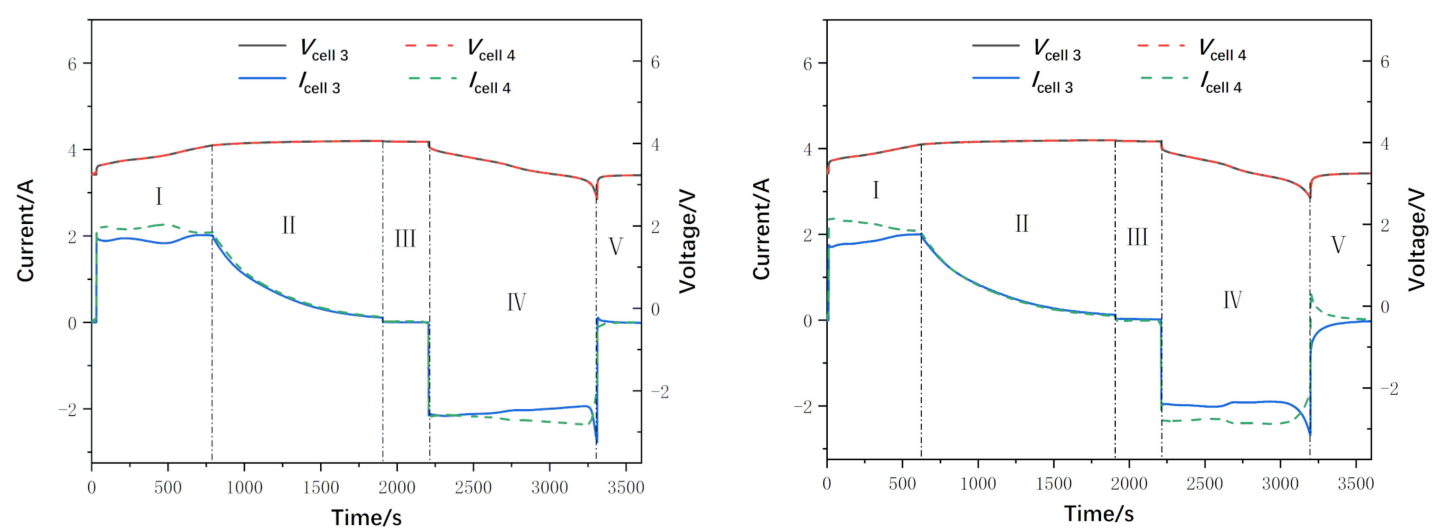

(b)
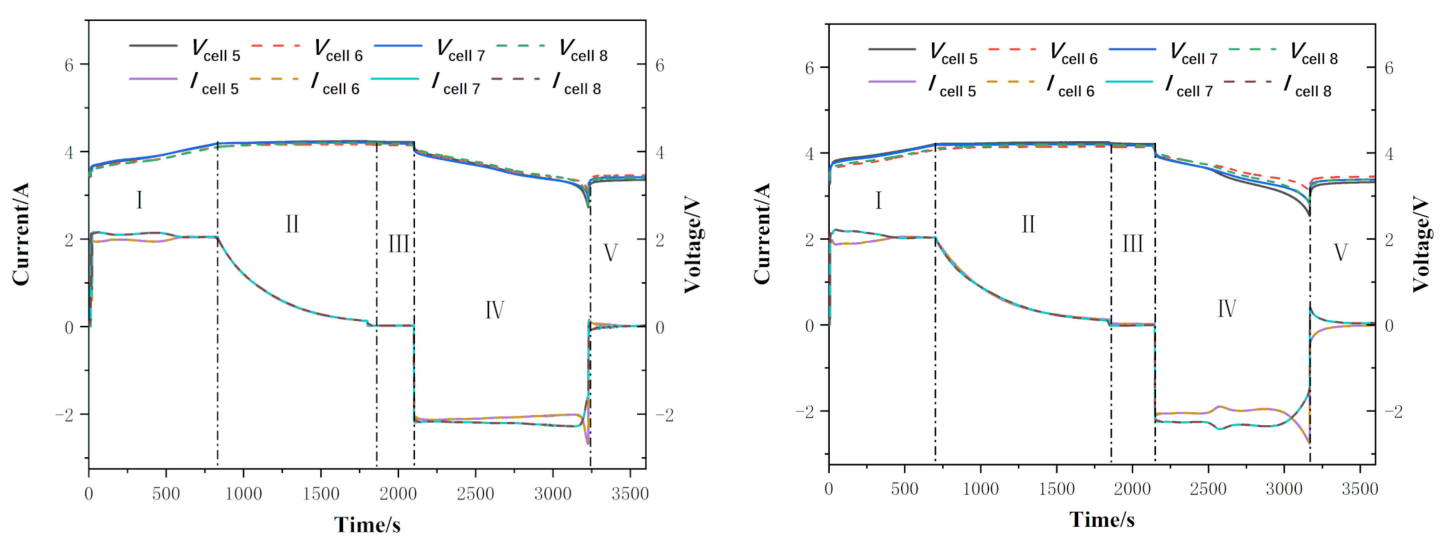

(c)
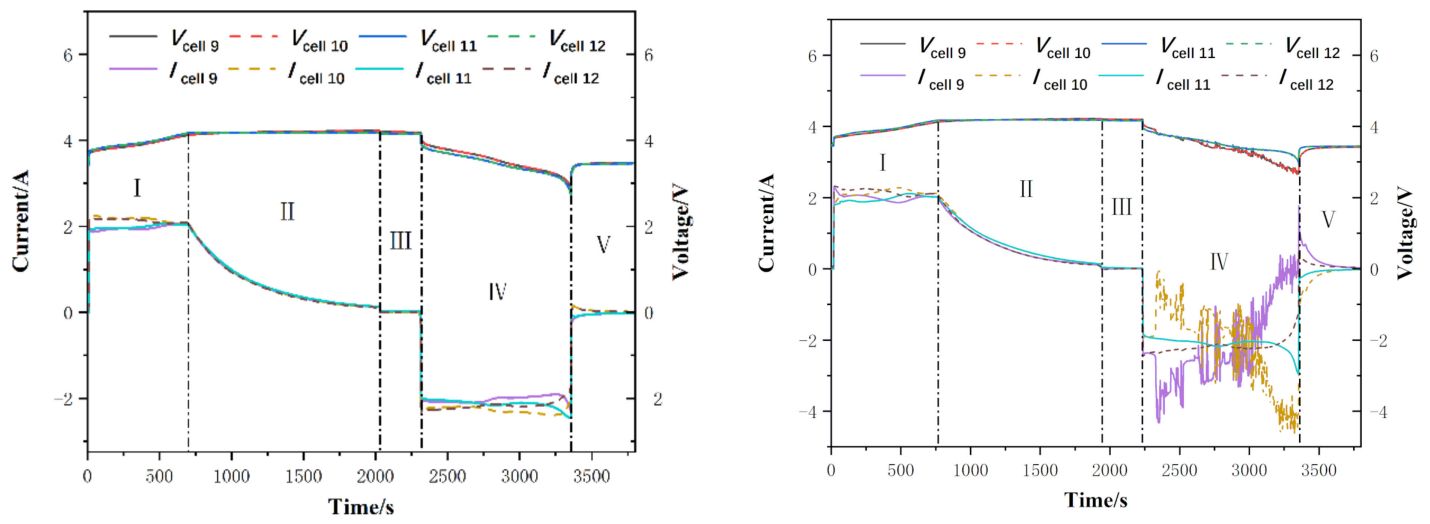

(d)

Figure 4. Comparison of charge and discharge profiles between cycle 5 and cycle 95: (a) Pack A; (b) Pack B; (c) Pack C; (d) Pack d.

1. The series configuration that primarily reflected the voltage difference:

The internal resistances of Cell-1 and Cell-2 were different due to the degree of degradation. The voltage of Cell-1 in phase I was significantly higher than that of Cell-2. During phase III, due to the weak discharge ability of Cell-1, the voltage was reduced faster and reduced more than that of Cell-2. In addition, the series configuration had good current consistency.

2. The parallel configuration that primarily reflected the current difference: 
The internal resistance of Cell-3 was larger than that of Cell-4. During phase I, the current of Cell-4 was less than that of Cell-3, which caused the charging current of Cell-4 to be greater than $2 \mathrm{C}$, and the charging cut-off voltage was reached in advance. Phase III was similar in that the Cell-4 discharge current exceeded $2 \mathrm{C}$ due to the internal resistance difference, and the capacity consumption was accelerated. At the end of phase III, as Cell-4 continued to discharge at a higher current, its discharge capacity and current began to decrease and the Cell-3 current increased at the same time. In phase $\mathrm{V}$, due to the difference in the open circuit voltage between the two cells, a significant circulation phenomenon was formed between the parallel circuits. The above phenomenon was likely to cause over-current and over-discharge for Cell-4. The parallel configuration had good voltage consistency.

3. The series-parallel configuration that reflected both the current and voltage differences:

The series-parallel connection can be regarded as a parallel module consisting of two series of cells. The unbalanced effect was similar to that in the above analysis. There was a voltage difference between the batteries connected in series and a significant current difference between the two branches, as well as a circulation phenomenon at the end of the discharge.

4. The parallel-series configuration that reflected both the current and voltage differences:

The parallel-series configuration can be seen as a series module consisting of two parallel cells. The unbalanced effect was similar to that in the above analysis. There was a voltage difference between the two series modules and a significant current difference between the two parallel circuits, as well as a circulation phenomenon at the end of the discharge.

At the same time, Figure 4 also shows the charge-discharge profiles of each battery pack at the beginning of charge-discharge (cycle 5) and the middle of charge-discharge (cycle 95). It can be seen from the figure that as the cycle increases, the unbalance effect gradually becomes more serious. When the battery pack is in an unbalanced state, there is significant inconsistency between the batteries. Regarding the internal resistance of the battery, the inconsistency of the internal resistance will cause uneven distribution of the discharge parameters. As the cycle increases, the effect becomes more and more obvious, and the specific performance is also related to the configuration of the battery pack.

1. For the series circuit, the voltage value of the degraded battery is significantly higher than that of the normal battery. Moreover, due to the higher internal resistance, the degraded battery increases the load in the circuit and accelerates the energy consumption of the battery pack, and there is also the risk of reverse voltage;

2. For the parallel circuit, due to the lower discharge capacity of the degraded battery and the higher resistance, the normal battery must make up for its insufficient discharge, causing the current of the normal battery to become higher than the set value.

Figure 5 shows the temperature curves of the charge-discharge profiles.

It can be seen from the temperature profile that there were certain regularities in the temperature changes of the individual cells in the four configurations. The temperatures of Pack A, Pack B, and Pack $\mathrm{C}$ all changed at nearly $28^{\circ} \mathrm{C}$, and the temperature of the degraded cells was higher than that of the other normal cells by $1-3^{\circ} \mathrm{C}$. The reason for this was that the degraded battery had a larger internal resistance. Pack D had a higher average battery temperature than the others. The temperature of Cell-10 was the highest, and the temperature in the late test was nearly $40^{\circ} \mathrm{C}$.

The changes in temperature are also related to the internal resistance. It can be seen from Figure 4 that the temperature of the degraded battery is higher due to the greater internal resistance. However, according to the previous discussion, the normal battery in the parallel circuit has an over-current phenomenon. As the cycle increases, the difference between cells increases, and the over-current phenomenon of the normal cell becomes more serious, which eventually leads to a sharp increase in temperature and failure. 


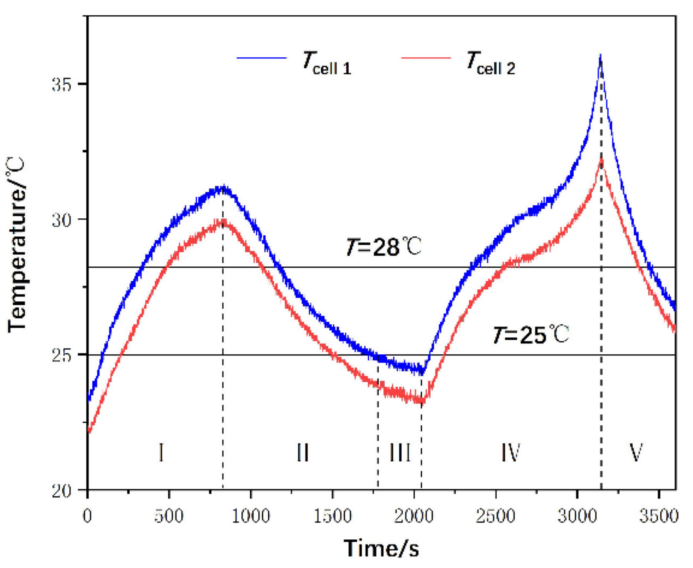

(a)

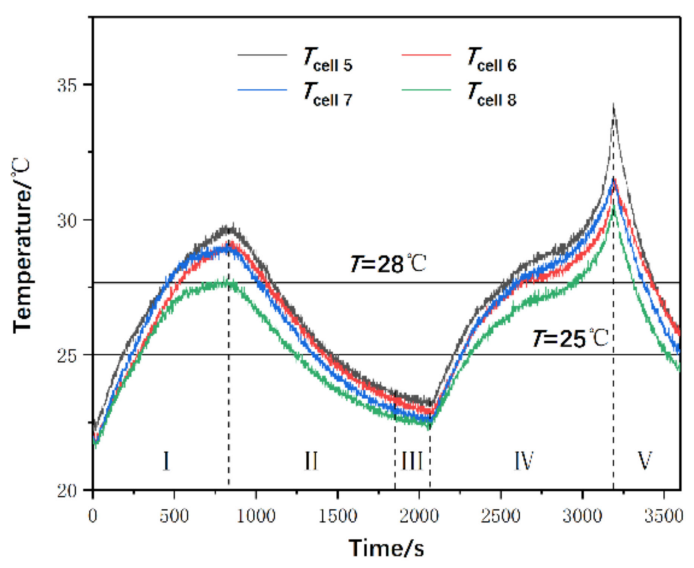

(c)

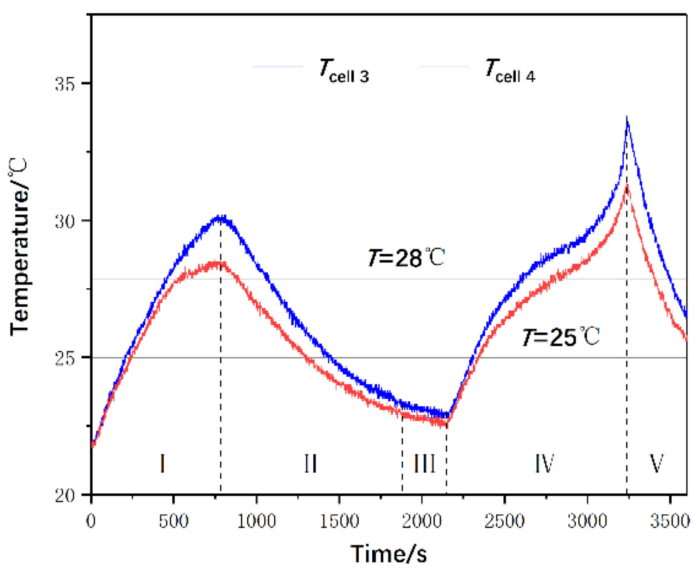

(b)

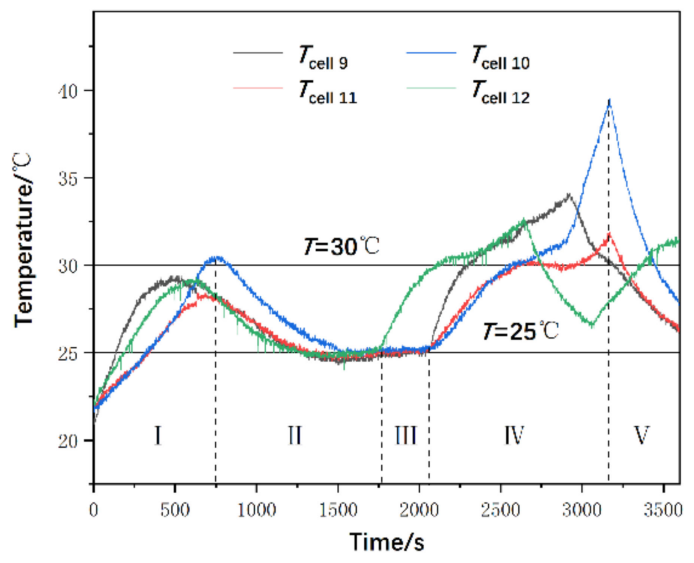

(d)

Figure 5. Surface temperatures of all the cells in the charge-discharge profiles: (a) Pack A; (b) Pack B; (c) Pack C; (d) Pack D.

Pack D of this test experienced significant failures in the battery pack after approximately 100 cycles. Figure 6 shows a charge-discharge parameter profile for the 95th cycle of Pack D.

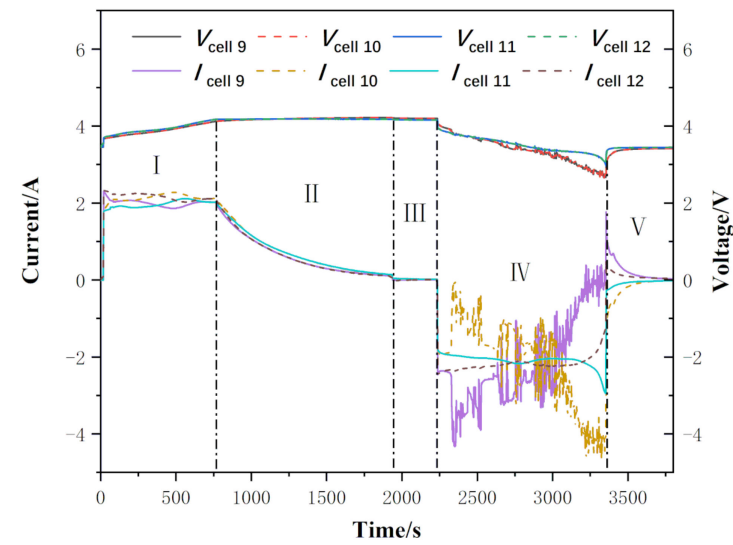

(a)

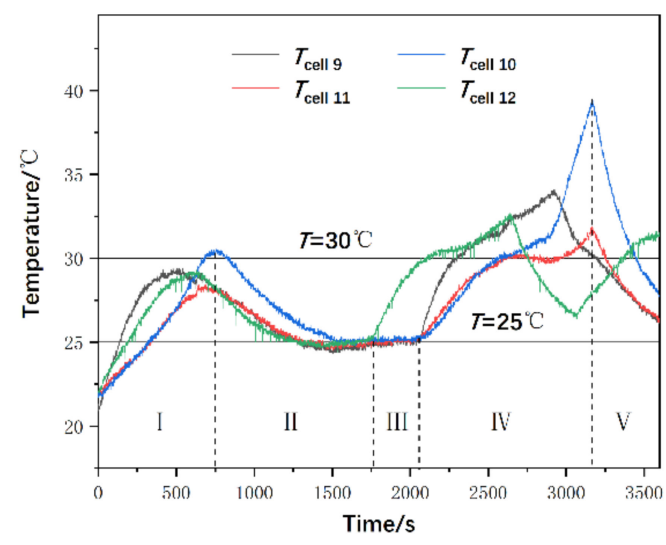

(b)

Figure 6. Pack D during the 95th charge-discharge profile: (a) current and voltage; (b) temperature. 
The failure manifested a sudden drop in the discharge capacity of the battery pack, and the current distribution became seriously out of balance. After detection, Cell-10 experienced failure. To ensure the safety of the test, the Pack D test was stopped. It can be seen from the 95th cycle parameters that the discharge current distributions of Cell- 9 and Cell-10 were severely unbalanced, and the discharge currents rose to approximately $4.5 \mathrm{~A}$, which was nearly twice the normal condition. This also caused Cell-10 to be in high-power operation. The increased heat generation and the speeding up of the battery degradation process made the highest temperature in the end nearly $40^{\circ} \mathrm{C}$.

According to the analysis, the degree of dependence of the four configurations of batteries under the unbalanced condition could be ranked as follows: Pack D $>$ Pack C $>$ Pack B $>$ Pack A. The degree of dependence of the unbalanced battery pack was related to the battery configuration. The degree of dependence of the parallel structure was greater than the series. The more complex the group structure was, the greater the degree of influence was.

\subsection{Degradation Process and Dependency Analysis}

\subsubsection{Capacity Degradation Process Analysis}

Discharge capacity can be used as an evaluation indicator of battery health or degradation. Over time, the dependence of a battery pack during the charge-discharge cycle accumulates, causing the degradation processes of cells to affect each other. In addition, the overall degradation process of the battery pack will be affected. Thus, it is important to analyze the dependence of a battery pack during the degradation process. In this study, the capacity degradation cumulative amount was used to characterize the battery degradation to ensure the same starting point and to facilitate a comparison of the results.

Figure 7 shows the cumulative capacity degradation of the four battery packs and cells. The first three battery packs contained 300 cycles of degradation, and Pack D contained only the data for 100 cycles prior to failure. The negative value of the degraded accumulation during the early cycles was due to the activation effect of the battery.

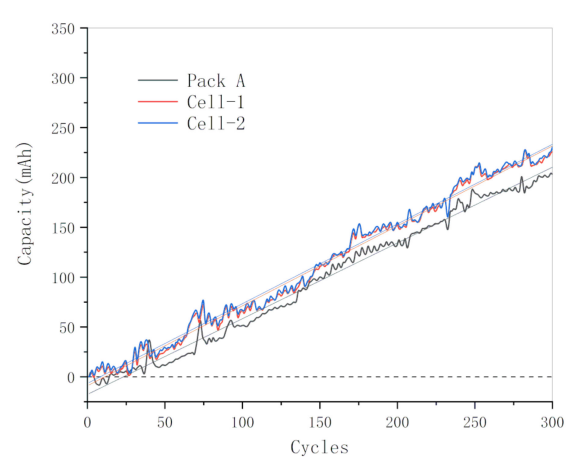

(a)

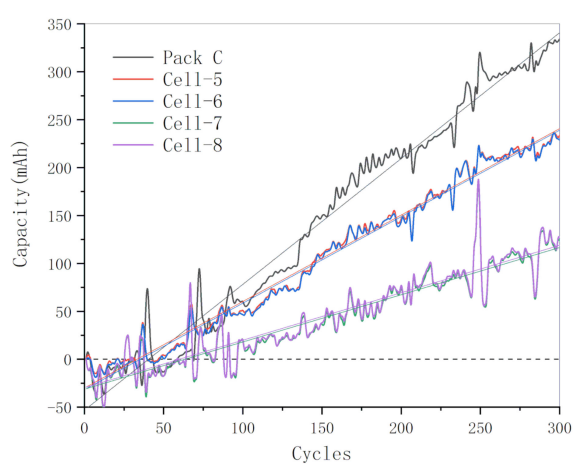

(c)

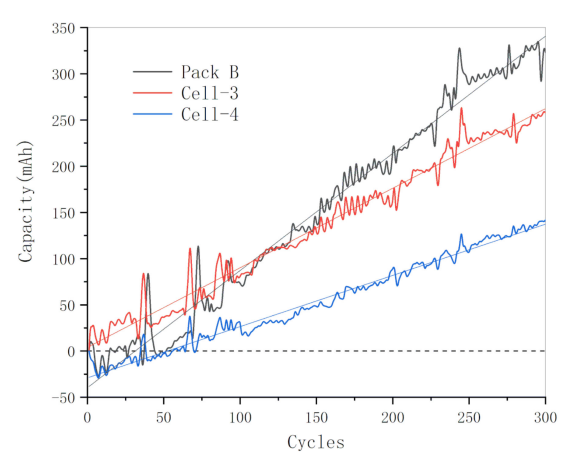

(b)

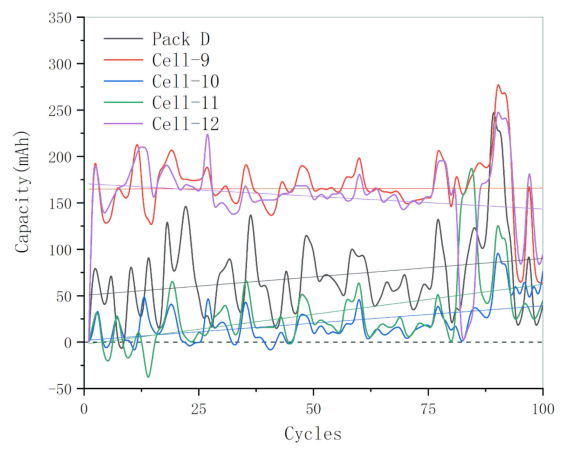

(d)

Figure 7. Battery pack discharge capacity degradation curve: (a) Pack A; (b) Pack B; (c) Pack C; (d) Pack D. 
The discharge capacity primarily depended on the discharge current. Therefore, the discharge capacity had good consistency in series. The parallel connection of the cells had a large difference in discharge capacity due to the obvious unbalance in the current distribution. It can be seen from the figure that the batteries connected in series in Pack A and Pack C maintained a relatively consistent degradation characteristic, but the rates of degradation of the cells in parallel with each other in Pack B and Pack C were quite different. Among them, Cell-3, as well as Cell-5 and Cell-6, were significantly more degraded than Cells 4,7 , and 8.

The difference in the degree of influence of cell degradation on the battery packs was described using the Pearson correlation coefficient (PCC). The PCC can reflect the degree of correlation between two variables, and it can be used to estimate the correlation strength between two variables based on the covariance matrix of the data $[35,36]$. Typically, the Pearson correlation coefficient of the two variables $\alpha_{i}, \alpha_{j}$ was:

$$
\rho\left(\alpha_{i}, \alpha_{j}\right)=\frac{\operatorname{cov}\left(\alpha_{i}, \alpha_{j}\right)}{\sqrt{\operatorname{var}\left(\alpha_{i}\right), \operatorname{var}\left(\alpha_{j}\right)}},
$$

where $\alpha$ is the capacity of the cells and packs.

The PCC between the cells and the battery pack in each configuration was calculated to observe the degradation inside the battery pack under unbalanced conditions. The results are shown in Table 5 .

Table 5. Pearson correlation matrix for capacity degradation in (a) Pack A; (b) Pack B; (c) Pack C; (d) Pack D.

\begin{tabular}{|c|c|c|c|c|c|c|c|}
\hline (a) & $Y_{\text {Cell-1 }}$ & & $\mathrm{Y}_{\text {Cell-2 }}$ & & & $\mathrm{Y}_{\text {Pack-A }}$ & \\
\hline $\mathrm{Y}_{\text {Cell-1 }}$ & 1 & & 0.9995 & & & 0.9910 & \\
\hline $\mathrm{Y}_{\mathrm{Cell-2}}$ & & & 1 & & & 0.9906 & \\
\hline$Y_{\text {Pack-A }}$ & & & & & & 1 & \\
\hline (b) & $\mathrm{Y}_{\text {Cell-3 }}$ & & $\mathrm{Y}_{\text {Cell-4 }}$ & & & $Y_{\text {Pack-B }}$ & \\
\hline $\mathrm{Y}_{\text {Cell-3 }}$ & 1 & & 0.9887 & & & 0.9750 & \\
\hline$Y_{\text {Cell-4 }}$ & & & 1 & & & 0.9123 & \\
\hline$Y_{\text {Pack-B }}$ & & & & & & 1 & \\
\hline (c) & $\mathrm{Y}_{\text {Cell-5 }}$ & $\mathrm{Y}_{\text {Cell-6 }}$ & & $\mathrm{Y}_{\text {Cell-7 }}$ & $\mathrm{Y}_{\text {Cell-8 }}$ & & $Y_{\text {Pack-C }}$ \\
\hline $\mathrm{Y}_{\text {Cell-5 }}$ & 1 & 0.9995 & & 0.9188 & 0.9178 & & 0.9856 \\
\hline $\mathrm{Y}_{\text {Cell-6 }}$ & & 1 & & 0.9181 & 0.9171 & & 0.9857 \\
\hline $\mathrm{Y}_{\text {Cell-7 }}$ & & & & 1 & 0.9990 & & 0.8999 \\
\hline $\mathrm{Y}_{\text {Cell-8 }}$ & & & & & 1 & & 0.8991 \\
\hline$Y_{\text {Pack-C }}$ & & & & & & & 1 \\
\hline (d) & $\mathrm{Y}_{\text {Cell-9 }}$ & $\mathrm{Y}_{\text {Cell-10 }}$ & & $\mathrm{Y}_{\text {Cell-11 }}$ & $\mathrm{Y}_{\text {Cell-12 }}$ & & $Y_{\text {Pack-D }}$ \\
\hline $\mathrm{Y}_{\text {Cell-9 }}$ & 1 & 0.5767 & & 0.3264 & 0.5750 & & 0.4570 \\
\hline $\mathrm{Y}_{\text {Cell-10 }}$ & & 1 & & 0.3664 & 0.4711 & & 0.2647 \\
\hline $\mathrm{Y}_{\text {Cell-11 }}$ & & & & 1 & -0.5109 & & 0.1485 \\
\hline $\mathrm{Y}_{\text {Cell-12 }}$ & & & & & 1 & & 0.2640 \\
\hline$Y_{\text {Pack-D }}$ & & & & & & & 1 \\
\hline
\end{tabular}

It was found that there was a strong correlation between the variables. The PCCs of the degraded cells in Pack B and Pack $C$ were slightly higher than those in the normal cells. That is to say, the degraded cells were more relevant to the battery pack than the normal cells were. The Pack A correlation coefficient was not significantly different.

Pack D was in an abnormal working state, and the data were highly volatile and had abnormal values. Therefore, the obtained data could not explain the dependence of the battery pack degradation, and this seriously affected the subsequent data analysis. 
In order to analyze the change in the capacity degradation rate of the cell and the battery pack during the first 300 cycles, the amount of degradation per cycle was defined as shown in Equation (2):

$$
\Delta C=C_{i+1}-C_{i},
$$

where $i$ is the number of cycles, and $C_{i}$ is the discharge capacity of the cycle. A change in $C_{i}$ indicates a change in the rate of degradation of the battery capacity as the number of cycles increased. Hence, the law of the degradation rate variation could then be more directly displayed.

The $C_{i}$ of Pack A, Pack B, and Pack C are shown in Figure 8.

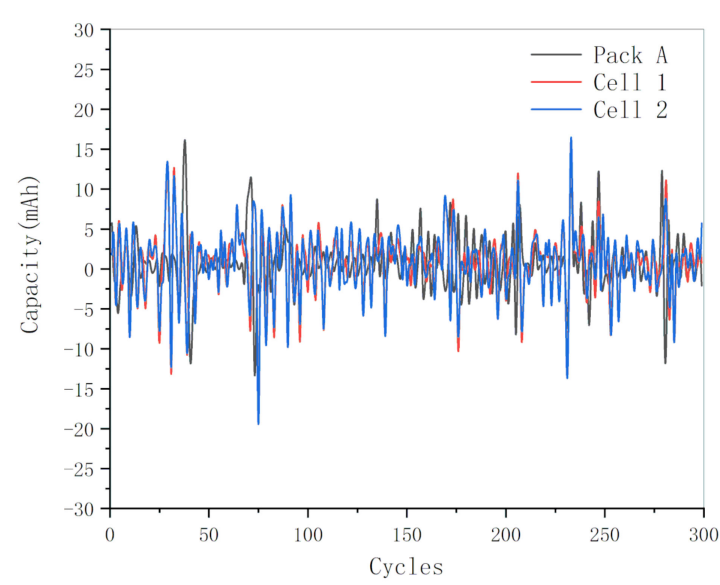

(a)

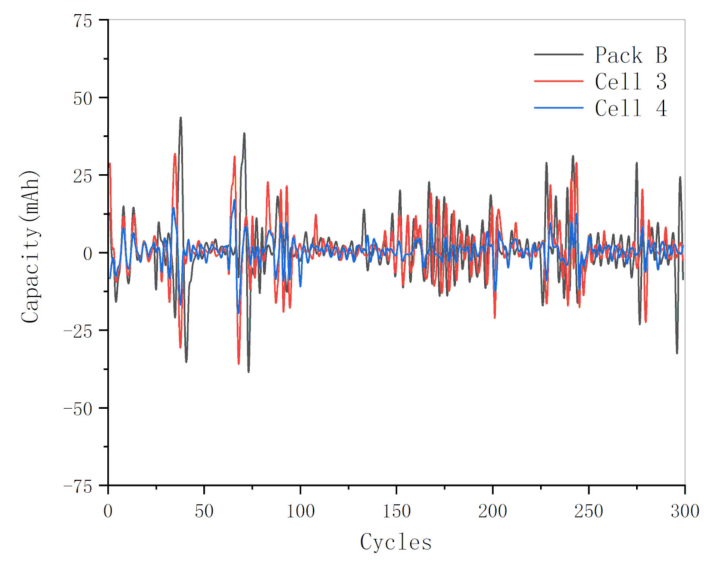

(b)

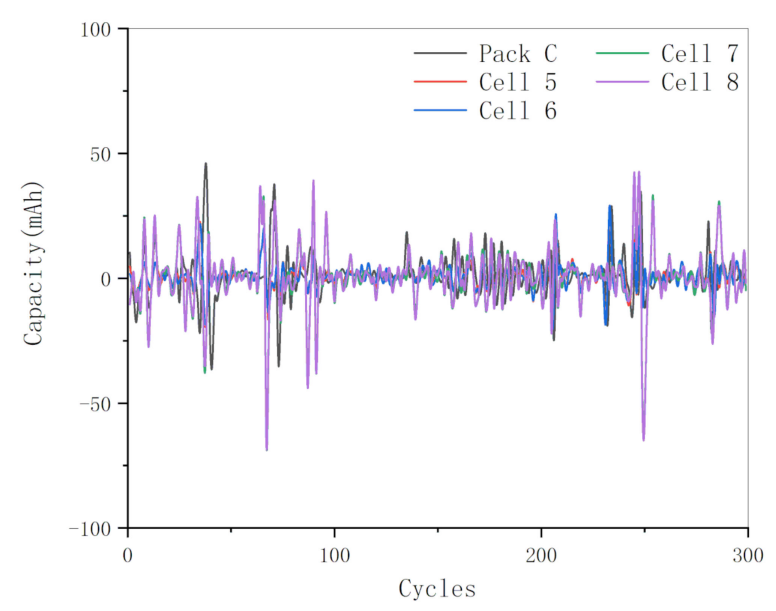

(c)

Figure 8. Inter-cycle capacity degradations: (a) Pack A; (b) Pack B; (c) Pack C.

When $C_{i}$ satisfied the normal distribution, it could be considered that there was no significant change in the rate of degradation of the battery capacity; that is, the rate of degradation did not increase as the cycle increased. Figure 9 shows how Pack A was used as an example to construct a histogram and a normal probability plot of the capacity degradation of each cell and battery pack. The other battery packs are shown in the Appendix A. 

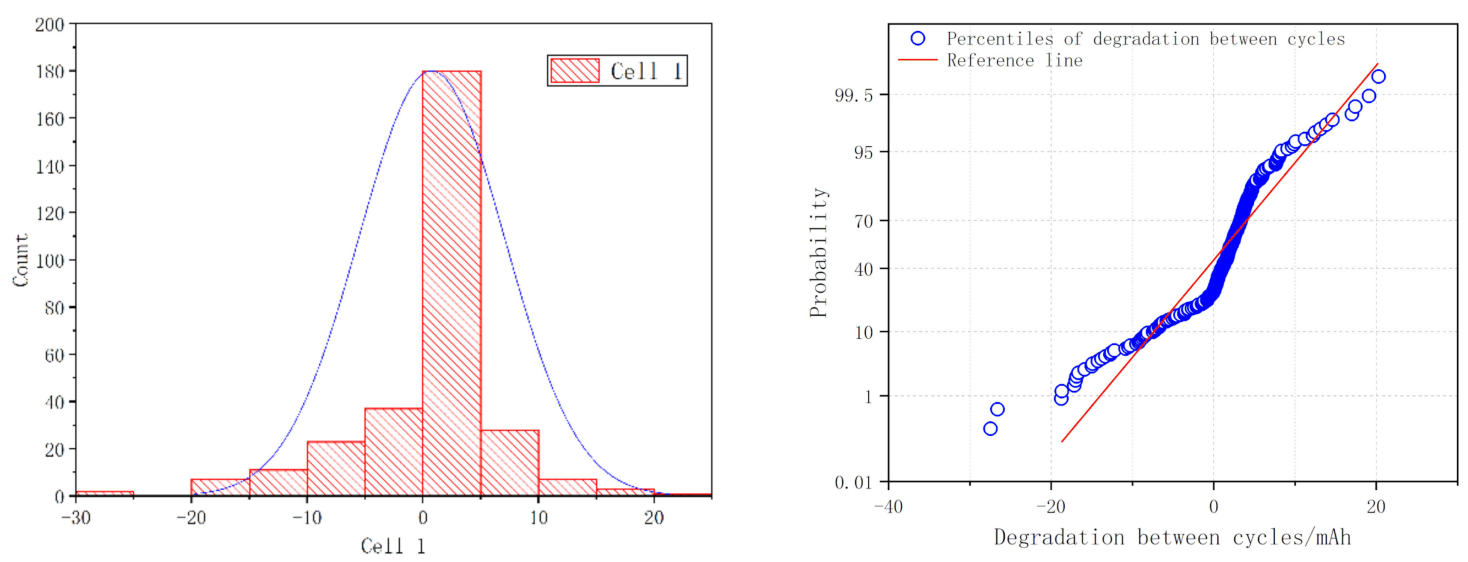

(a)
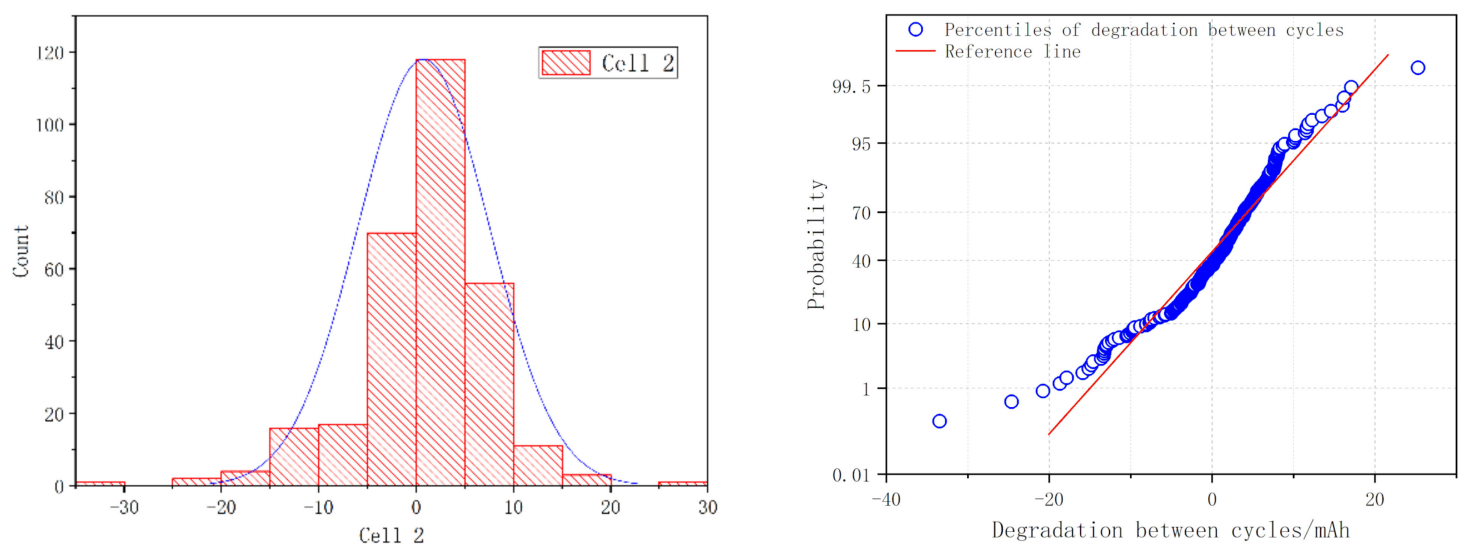

(b)
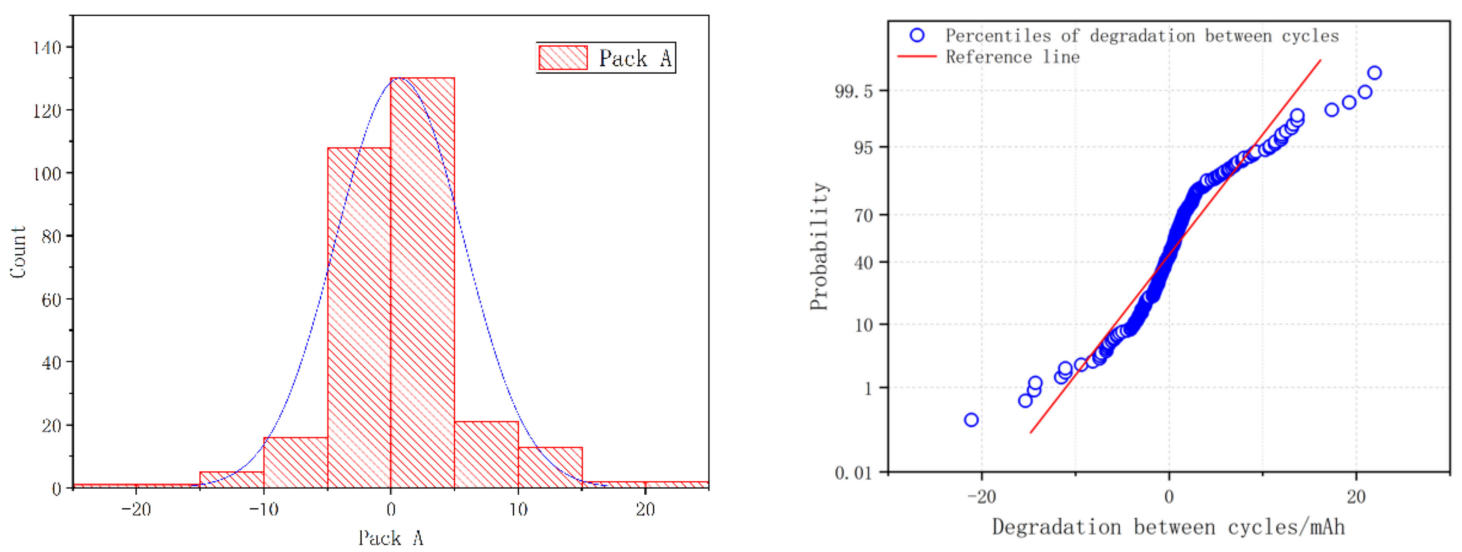

(c)

Figure 9. Probability map of the capacity degradation between cycles: (a) Cell-1; (b) Cell-2; (c) Pack A.

In order to verify that the amount of degradation between cycles followed a normal distribution, the cell and the battery were tested for normality. Table 6 shows the means and variances of the normal distribution of the three configurations, as well as the $p$-values of the normal test. It was generally considered that if the $p$-value was greater than 0.05 , the data were considered to be from a normal population. 
Table 6. Normality test results.

\begin{tabular}{|c|c|c|c|c|c|c|c|}
\hline & Pack-A & & Cell-1 & & & Cell-2 & \\
\hline mu & 0.6789 & & 0.7545 & & & 0.7712 & \\
\hline sigma & 5.0358 & & 6.3175 & & & 6.7718 & \\
\hline \multirow[t]{2}{*}{$p$-value } & $>0.05$ & & $>0.05$ & & & $>0.05$ & \\
\hline & Pack-B & & Cell-3 & & & Cell-4 & \\
\hline mu & 1.0801 & & 0.8617 & & & 0.4764 & \\
\hline sigma & 13.7966 & & 12.5706 & & & 6.1109 & \\
\hline \multirow[t]{2}{*}{$p$-value } & $>0.05$ & & $>0.05$ & & & $>0.05$ & \\
\hline & Pack-C & Cell-5 & & Cell-6 & Cell-7 & & Cell-8 \\
\hline mu & 1.2921 & 0.6813 & & 0.6822 & 0.4124 & & 0.4112 \\
\hline sigma & 24.4506 & 7.5422 & & 7.4526 & 7.7252 & & 7.6654 \\
\hline$p$-value & $>0.05$ & $>0.05$ & & $>0.05$ & $>0.05$ & & $>0.05$ \\
\hline
\end{tabular}

The amount of degradation between cycles for each battery pack and the cells in the first 300 cycles represented a normal distribution. There was no significant change in the rate of degradation during the first 300 cycles. That is, the degradation rate did not increase with an increase in the cycle during the first 300 cycles. This provided a basis for the establishment of the regression analysis for the subsequent degradation processes.

Due to the dependence effect, there was a significant difference in the degradation process between the battery pack and the cells in the unbalanced state. Quantifying the difference in the degradation process helped us to explore the influence of the unbalanced state on the degradation process of the battery packs. According to the above analysis, the degradation process of the battery pack during the 300 cycles conformed to the linear law. A linear regression model was then used to establish the degradation model:

$$
z=\beta_{0}+\sum_{k=1}^{q} \beta_{k} x_{k} \quad k=1,2, \ldots, q,
$$

where $z$ represents the cumulative amount of capacity degradation, and the slope $\beta_{k}$ represents the rate of capacity degradation. The degradation rates of the respective battery packs and cells are shown in Table 7 .

Table 7. Capacity degradation rates of the battery packs and cells.

\begin{tabular}{|c|c|c|c|}
\hline Pack No. & Degradation Rate & Cell No. & Degradation Rate \\
\hline \multirow[t]{2}{*}{ Pack-A } & 0.7998 & Cell-1 & 0.8019 \\
\hline & & Cell-2 & 0.8020 \\
\hline \multirow[t]{2}{*}{ Pack-B } & 1.2681 & Cell-3 & 0.8613 \\
\hline & & Cell-4 & 0.5543 \\
\hline \multirow[t]{4}{*}{ Pack-C } & 1.3131 & Cell-5 & 0.9024 \\
\hline & & Cell-6 & 0.9055 \\
\hline & & Cell-7 & 0.4931 \\
\hline & & Cell-8 & 0.4930 \\
\hline \multirow[t]{4}{*}{ Pack-D } & 0.3970 & Cell-9 & 0.0103 \\
\hline & & Cell-10 & 0.3730 \\
\hline & & Cell-11 & 0.6448 \\
\hline & & Cell-12 & -0.2737 \\
\hline
\end{tabular}

As can be seen from Table 7:

1. When the normal cell was connected in series with the degraded cell, the degradation rate did not show a large difference.

2. When the normal cell was connected in parallel with the degraded cell, the degradation rate of the normal cell was significantly smaller than that of the degraded cell. 
3. The degradation rates of Pack $\mathrm{A}$ and its cells were not significantly different. The degradation rates of Pack B and Pack $C$ were significantly higher than the rates of their cells.

When the degraded cell was connected in parallel with the normal cell, the internal resistance of the degraded battery was large, which directly led to a small current being divided during the constant current charging and discharging process. In contrast, the normal cell charged and discharged with a larger current. The calculation of the discharge capacity was primarily related to the discharge current, so the normal cell discharged more power per cycle, thereby appearing to be smaller than the degraded battery at the rate of capacity degradation.

\subsubsection{Dependency Analysis of the Battery Packs}

In the unbalanced state, there was data collinearity between the individual cells and the battery pack due to their strong dependence. Therefore, the data collinearity needed to be overcome to obtain a more accurate degradation-dependent regression model.

In this research, the PLSR was used to quantify the dependence of the battery pack in the unbalanced state to explore the degree of influence of the components in the unbalanced state.

The cycle discharge capacity of single cells was selected as the independent variable, and the battery pack discharge capacity and the maximum temperature in every cycle of each single cell were selected as the dependent variables:

$$
C_{i}=\left[\begin{array}{c}
C_{i 1} \\
\vdots \\
C_{i n}
\end{array}\right], P=\left[\begin{array}{c}
P_{1} \\
\vdots \\
P_{n}
\end{array}\right], T_{i}=\left[\begin{array}{c}
T_{i 1} \\
\vdots \\
T_{i n}
\end{array}\right],
$$

where $i$ is the battery number and $n$ is the cycle number, 300. For each configuration, $C_{i}$ is the discharge capacity vector of the $i$ battery; $P$ is the discharge capacity vector of the battery pack; and $P$ is the cycle maximum temperature vector of the -th battery.

Putting the data after standardization into the matrix, the following was obtained:

$$
A=\left[\begin{array}{ccc}
C_{11} & \cdots & C_{1 m} \\
\vdots & \ddots & \vdots \\
C_{n 1} & \cdots & C_{n m}
\end{array}\right], B=\left[\begin{array}{ccc}
P_{1} & \cdots & T_{1 m} \\
\vdots & \ddots & \vdots \\
P_{n} & \cdots & T_{n m}
\end{array}\right]
$$

where $m$ is the number of batteries. The matrices A and B were written as:

$$
A=\left[\begin{array}{ccc}
a_{11} & \cdots & a_{1 m} \\
\vdots & \ddots & \vdots \\
a_{n 1} & \cdots & a_{n m}
\end{array}\right], B=\left[\begin{array}{ccc}
b_{11} & \cdots & b_{1 p} \\
\vdots & \ddots & \vdots \\
b_{n 1} & \cdots & b_{n p}
\end{array}\right] .
$$

The first pair of components, $u_{1}$ and $v_{1}$, was extracted from the two sets of variables:

$$
\begin{aligned}
& u_{1}=\alpha_{11} x_{1}+\cdots+\alpha_{1 m} x_{m}=\rho^{(1) T} X ; \\
& v_{1}=\beta_{11} y_{1}+\cdots+\beta_{1 p} y_{p}=\gamma^{(1) T} T .
\end{aligned}
$$

$u_{1}$ and $v_{1}$ had to satisfy the following:

$u_{1}$ and $v_{1}$ had to extract as much variation information as possible from the variable group; $u_{1}$ and $v_{1}$ had the highest degree of correlation. 
The score vector of the first pair of components was calculated and denoted as $\hat{u}_{1}$ and $\hat{v}_{1}$ :

$$
\begin{gathered}
\hat{u}_{1}=A \rho^{(1)}=\left[\begin{array}{ccc}
a_{11} & \cdots & a_{1 m} \\
\vdots & \ddots & \vdots \\
a_{n 1} & \cdots & a_{n m}
\end{array}\right]\left[\begin{array}{c}
\alpha_{11} \\
\vdots \\
\alpha_{1 m}
\end{array}\right] ; \\
\hat{v}_{1}=B \gamma^{(1)}=\left[\begin{array}{ccc}
b_{11} & \cdots & b_{1 p} \\
\vdots & \ddots & \vdots \\
b_{n 1} & \cdots & b_{n p}
\end{array}\right]\left[\begin{array}{c}
\beta_{11} \\
\vdots \\
\beta_{1 p}
\end{array}\right] .
\end{gathered}
$$

The covariance, $\operatorname{Cov}\left(u_{1}, v_{1}\right)$, of the first pair of components, $u_{1}$ and $v_{1}$, could be calculated from the inner product of the score vector sum of the first pair of components.

$$
\begin{gathered}
\max \left(\hat{u}_{1} \cdot \hat{v}_{1}\right)=\left(A \rho^{(1)} \cdot B \gamma^{(1)}\right)=\rho^{(1) T} A^{T} B \gamma^{(1)} ; \\
\text { s.t. }\left\{\begin{array}{l}
\rho^{(1) T} \rho^{(1)}=\left\|\rho^{(1)}\right\|^{2}=1 \\
\gamma^{(1) T} \gamma^{(1)}=\left\|\gamma^{(1)}\right\|^{2}=1
\end{array}\right.
\end{gathered}
$$

Using the Lagrange multiplier method, the problem was solved by finding the unit vectors, $\rho^{(1)}$ and $\gamma^{(1)}$, to maximize $\theta_{1}=\rho^{(1) T} A^{T} B \gamma^{(1)}$. By calculating the eigenvalues and eigenvectors of the $m \times m$ matrix $M=A^{T} B B^{T} A$, the maximum eigenvalue of $M$ was $\theta_{1}{ }^{2}$, the corresponding unit eigenvector was the obtained solution $\rho^{(1)}$, and $\gamma^{(1)}$ could be calculated with $\rho^{(1)}$.

$$
\gamma^{(1)}=\frac{1}{\theta_{1}} B^{T} A \rho^{(1)}
$$

The regression model was:

$$
\left\{\begin{array}{c}
A=\hat{u}_{1} \sigma^{(1) T}+A_{1} \\
B=\hat{v}_{1} \tau^{(1) T}+B_{1}
\end{array}\right.
$$

where $\sigma^{(1)}=\left[\sigma_{11}, \cdots, \sigma_{1 m}\right]^{T}$ and $\tau^{(1)}=\left[\tau_{11}, \cdots, \tau_{1 p}\right]^{T}$ are the parameter vectors in the regression model, indicating the degree of influence of the independent variables on the dependent variable. $A_{1}$ and $B_{1}$ are the residual error matrices.

The PLSR estimation of the regression coefficient vectors, $\sigma^{(1)}$ and $\tau^{(1)}$, was:

$$
\left\{\begin{aligned}
\sigma^{(1)} & =A^{T} \hat{u}_{1} /\left\|\hat{u}_{1}\right\|^{2} \\
\tau^{(1)} & =B^{T} \hat{v}_{1} /\left\|\hat{v}_{1}\right\|^{2}
\end{aligned}\right.
$$

By defining $\hat{A}=\hat{u}_{1} \sigma^{(1) T}$ and $\hat{B}=\hat{v}_{1} \tau^{(1) T}$, then the residual matrices had to be $A_{1}=A-\hat{A}$ and $B_{1}=B-\hat{B}$.

The cross-validity was defined as:

$$
Q_{h}^{2}=1-\operatorname{PRESS}(h) / S S(h-1),
$$

where

$$
\begin{gathered}
\operatorname{PRESS}(h)=\sum_{i=1}^{p} \operatorname{PRESS}_{j}(h)=\sum_{i=1}^{p} \sum_{j=1}^{n}\left(b_{i j}-\hat{b}_{(i) j}(h)\right)^{2}, \text { and } \\
S S(h)=\sum_{i=1}^{p} S S_{j}(h)=\sum_{i=1}^{p} \sum_{j=1}^{n}\left(b_{i j}-\hat{b}_{i j}(h)\right)^{2} .
\end{gathered}
$$

A cross-validity test was performed before the end of each step of the modeling. If there was $Q_{h}^{2}<1-0.95^{2}=0.0975$ in step $h$, the model met the accuracy requirement and it could stop extracting 
components. If $Q_{h}^{2} \geq 0.0975$, this indicated that the marginal contribution rate of the $u_{h}$ component extracted in the $h$-th step was significant, and the calculation in the $h+1$-th step had to be continued. Finally, the extraction of $h$ components produced:

$$
\left\{\begin{array}{c}
A=\hat{u}_{1} \sigma^{(1) T}+\cdots+\hat{u}_{h} \sigma^{(h) T}+A_{h} \\
B=\hat{v}_{1} \tau^{(1) T}+\cdots+\hat{v}_{h} \tau^{(h) T}+B_{h}
\end{array} .\right.
$$

By substituting $u_{k}=\alpha_{k 1} x_{1}+\cdots+\alpha_{k m} x_{m}(k=1,2, \cdots, r)$ into $Y=u_{1} \tau^{(1)}+\cdots+u_{h} \tau^{(h)}$, the PLSR equation of $p$ dependent variables was obtained:

$$
y_{j}=c_{j 1} x_{1}+\cdots+c_{j m} x_{m},(j=1,2, \cdots, p)
$$

$\mathrm{R}^{2}$ was then used as the evaluation index of the model:

$$
R^{2}=1-\frac{\sum\left(Y_{-} \text {actual }-Y_{\_} \text {predict }\right)^{2}}{\sum\left(Y_{\text {actual }}-Y_{\_} \text {mean }\right)^{2}} .
$$

The standardized parameters reflect the degree of influence of each variable on the dependent variable and the correlation between the independent variables. The normalized coefficients for the

\begin{tabular}{|c|c|c|c|c|c|c|c|}
\hline Pack-A & $\mathrm{Y}_{\text {Pack-A }}$ & & $\mathrm{T}_{\text {Cell-1 }}$ & & & $\mathrm{T}_{\text {Cell-2 }}$ & \\
\hline $\mathrm{Y}_{\text {Cell-1 }}$ & 0.4936 & & -0.4968 & & & -0.1104 & \\
\hline $\mathrm{Y}_{\text {Cell-2 }}$ & 0.4936 & & -0.4967 & & & -0.1104 & \\
\hline $\mathrm{N}_{\text {comp }}$ & 2 & & & & & & \\
\hline $\mathrm{R}^{2}$ & 0.9824 & & 0.8323 & & & 0.9405 & \\
\hline Pack-B & $Y_{\text {Pack-B }}$ & & $\mathrm{T}_{\text {Cell-3 }}$ & & & $\mathrm{T}_{\text {Cell-4 }}$ & \\
\hline $\mathrm{Y}_{\text {Cell-3 }}$ & 0.5391 & & -0.1781 & & & -0.0797 & \\
\hline$Y_{\text {Cell-4 }}$ & 0.4664 & & -0.2226 & & & -0.1875 & \\
\hline $\mathrm{N}_{\text {comp }}$ & 2 & & & & & & \\
\hline & 0.9521 & & 0.9082 & & & 0.9378 & \\
\hline Pack-C & $Y_{\text {Pack-C }}$ & $\mathrm{T}_{\text {Cell- } 5}$ & & $\mathrm{~T}_{\text {Cell-6 }}$ & $\mathrm{T}_{\text {Cell-7 }}$ & & $\mathrm{T}_{\text {Cell-8 }}$ \\
\hline $\mathrm{Y}_{\text {Cell-5 }}$ & 0.2240 & -0.1681 & & -0.0424 & -0.0345 & & -0.0114 \\
\hline $\mathrm{Y}_{\text {Cell-6 }}$ & 0.2241 & -0.1681 & & -0.0424 & -0.0345 & & -0.0114 \\
\hline $\mathrm{Y}_{\text {Cell-7 }}$ & 0.2100 & -0.2019 & & -0.0742 & -0.0658 & & -0.0417 \\
\hline $\mathrm{Y}_{\text {Cell-8 }}$ & 0.2100 & -0.2019 & & -0.0742 & -0.0658 & & -0.0417 \\
\hline $\mathrm{N}_{\text {comp }}$ & 2 & & & & & & \\
\hline $\mathrm{R}^{2}$ & 0.9300 & 0.9018 & & 0.9068 & 0.9133 & & 0.9050 \\
\hline
\end{tabular}
PLSR of the battery pack and the $\mathrm{R}^{2}$ values are shown in Table 8. below:

Table 8. Unbalanced model normalization coefficient.

Figure 10 shows the histograms of the absolute values of the standard regression coefficients.

It should be noted here that the capacity of the individual cells in the independent variables needed to be a decreasing process according to the actual process. Therefore, in this process, the battery pack capacity was continuously reduced (the coefficient was positive), and the temperature of each unit cell was continuously increased (the coefficient was negative). 


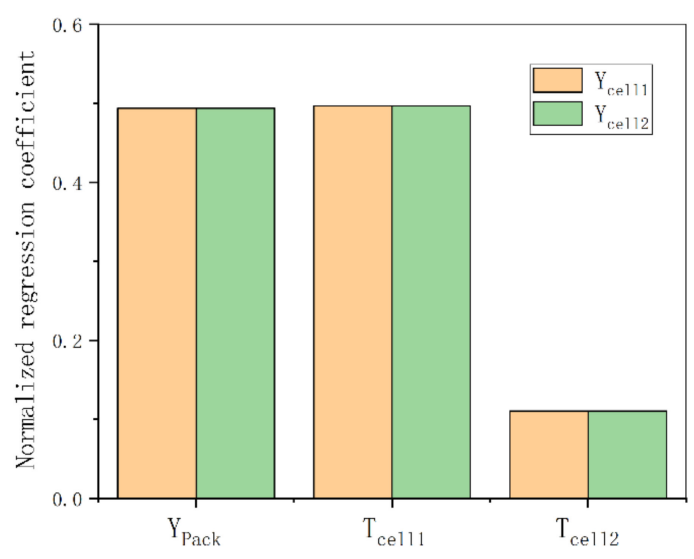

(a)

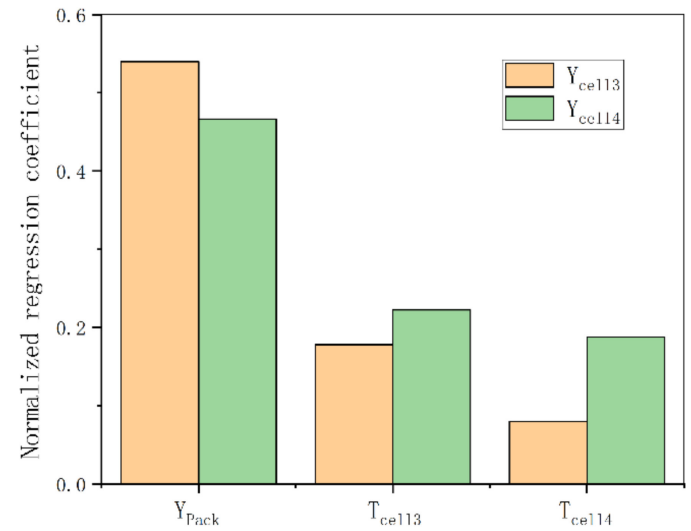

(b)

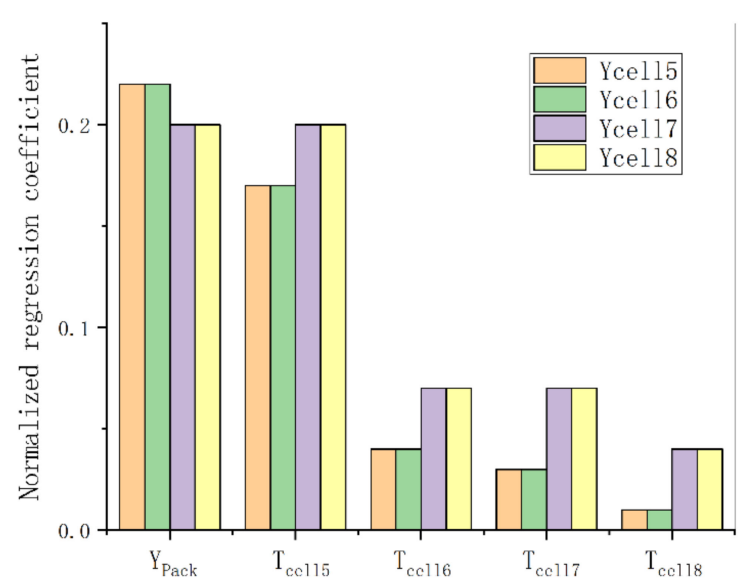

(c)

Figure 10. Normalized coefficient histograms: (a) Pack A; (b) Pack; (c) Pack C.

The absolute value of the standard regression coefficient indicated the degree of influence of the cell degradation on the dependent variable. The difference in the coefficient reflected the difference in the degree of influence of each cell on the dependent variable:

1. Cell-1 and Cell-2 in Pack A had the same effect on the battery degradation and temperature.

2. The effect of Cell-3 on the capacity of the battery pack in Pack B was significantly higher than that of Cell-4. However, for the impact on temperature, Cell-4 is higher than Cell-3. Based on previous analysis and test results, in the unbalanced state, the normal cell in the parallel structure will demonstrate an over-current phenomenon because it must compensate for the insufficient discharge capacity of the degraded cell. As the cycle increases, the difference between the cells becomes greater, and the current load of the normal battery also becomes greater. It can be seen from the formula $Q=I^{2} R$ that the heat of the battery increases with the current squared. Therefore, when the difference between batteries reaches a certain level, the influence of normal batteries on temperature plays a leading role.

3. Pack C combined the characteristics of Pack A and Pack B, and the battery in series had the same degree of influence. In addition, there was a significant difference in the degree of influence of the parallel battery.

4. The temperature of the degraded cells was affected by the cells more than it was by the normal cells. 


\section{Conclusions}

In this study, degradation tests of four configuration lithium-ion battery packs were conducted. The influence of the unbalanced dependence on the battery packs was found to be related to the configuration. The degree of influence in the parallel configuration was greater than that for the series configuration, and the more complex the configuration was, the more serious influence it had. In addition, the unbalanced state accelerated the degradation process of the battery packs. The specific performances included over-discharge, over-current, reverse charging, and high temperature. Next, a model was built to quantitatively analyze the degradation process and dependence of the battery pack. The linear regression model was used to analyze the degradation process of the battery pack and to determine that the difference in the degradation rate between cells can reach around 1.5 times. Then, the quantitative model of battery dependence was established by PLSR. When the initial capacity difference reached $5 \%$, the difference in dependence degree between the cells with poorer performance and the cells with better performance was as high as 2-3 times, which was especially obvious in the parallel circuits. A high regression coefficient $\left(R^{2}>0.9\right)$ indicated that the degradation process dependency could be quantified. In the future, we will conduct further analysis on the different degrees of unbalanced state and the more complex battery configurations. At present, degradation tests are carried out for batteries with a $5 \%$ difference in initial capacity. In order to study the unbalanced effects of battery packs under different unbalance levels, it is planned to design battery combinations with different degradation states for cycle degradation tests. At the same time, one should consider extrapolating the results to commonly used commercial lithium-ion battery packs for relevant analysis.

Author Contributions: X.W. and L.W. proposed the idea of the research and analyzed the theory. X.W. and Y.S. designed and implemented the experiments. S.L. processed and analyzed the data. S.L. and L.W. built the model. S.L. and X.W. wrote the original manuscript. L.W. and Z.W. reviewed and edited the manuscript. All authors have read and agreed to the published version of the manuscript.

Funding: This work was funded by the Strategic Leading Science \& Technology Program (Class A) of the Chinese Academy of Sciences (grant number XDA14000000), the National Natural Science Foundation of China (No. 51805016), and the Fundamental Research Funds for the Central Universities (grant number. YWF-20-BJ-J-908).

Conflicts of Interest: The authors declare no conflict of interest.

\section{Glossary}

$\begin{array}{ll}\alpha & \text { Variable } \\ C & \text { Discharge capacity } \\ \beta & \text { Capacity degradation rate } \\ z & \text { Capacity degradation mAh } \\ \rho & \text { Correlation coefficient } \\ i & \text { Charge-discharge cycle } \\ A & \text { Matrix containing the independent variables } \\ B & \text { Matrix containing the dependent variables } \\ u & \text { Principal component vector of A } \\ v & \text { Principal component vector of B } \\ \hat{u} & \text { Score vector of } u \\ \hat{v} & \text { Score vector of } v \\ \sigma & \text { Regression coefficient for independent variables } \\ \tau & \text { Regression coefficient for dependent variables } \\ Q_{h}^{2} & \text { Cross-validity test coefficient }\end{array}$




\section{Appendix A}
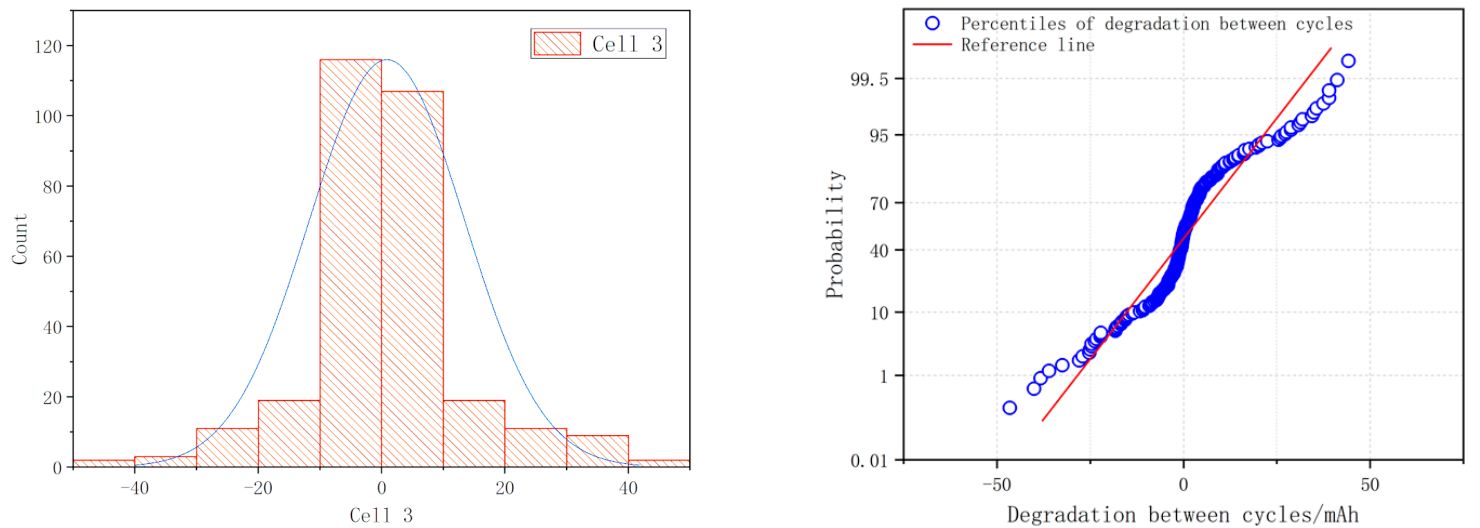

(a)
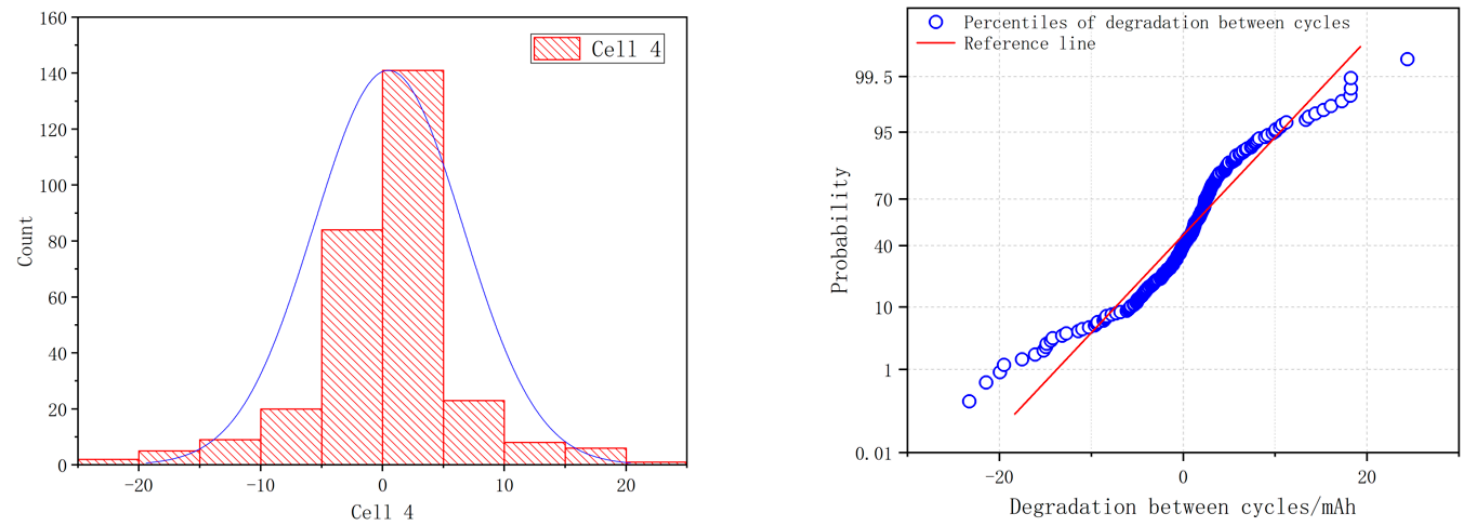

(b)
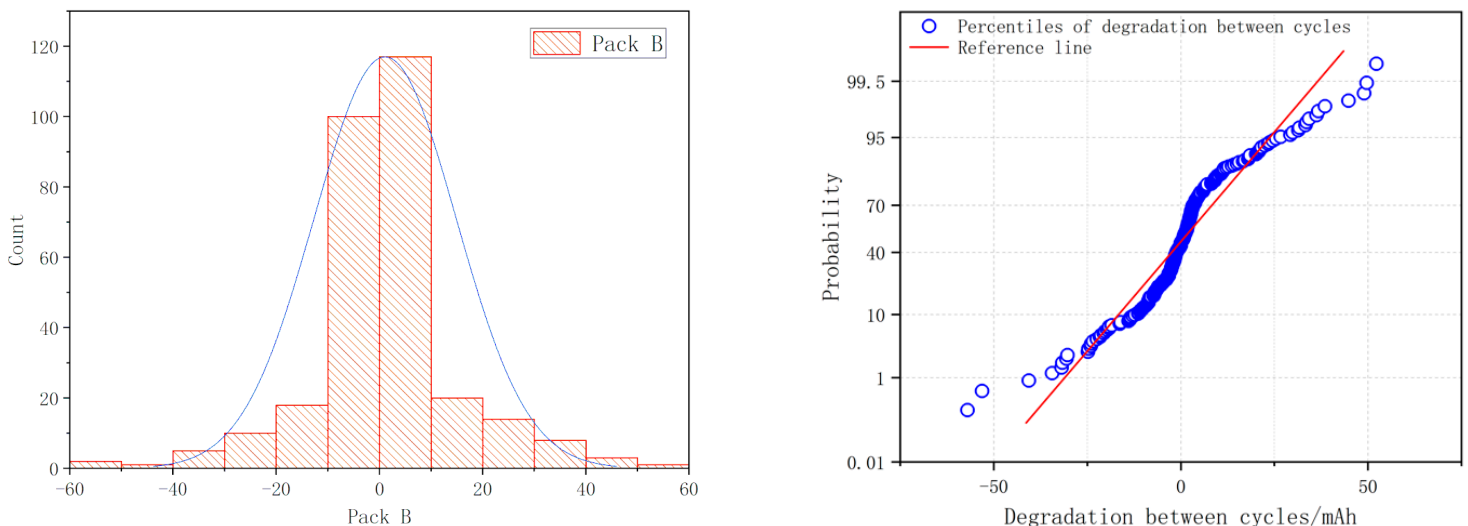

(c)

Figure A1. Probability map of capacity degradations between cycles: (a) Cell-3; (b) Cell-4; (c) Pack B. 

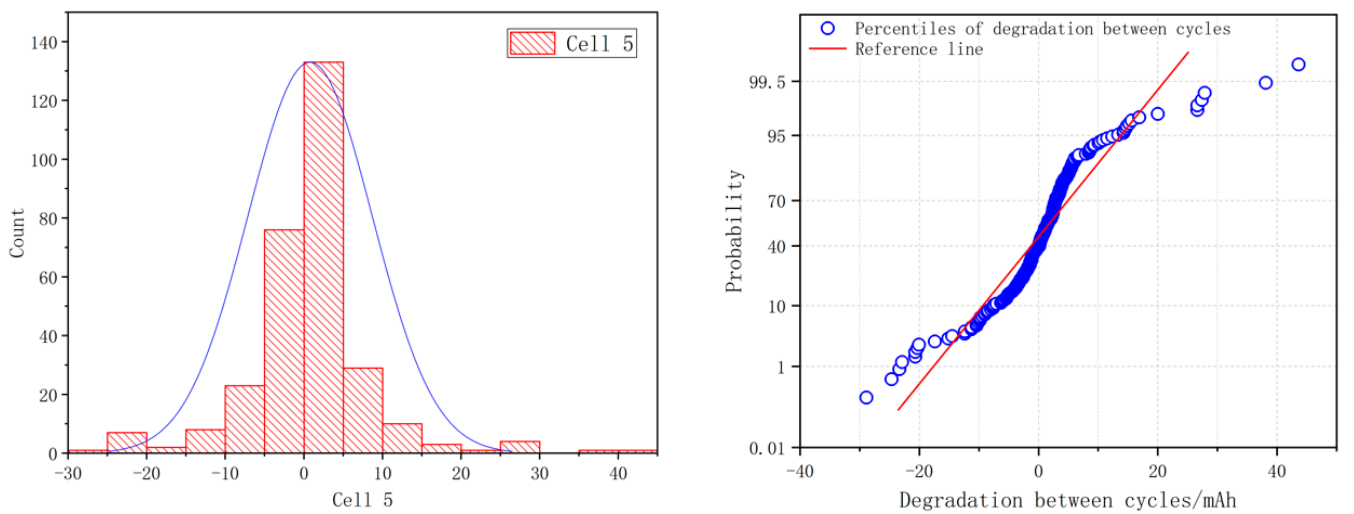

(a)
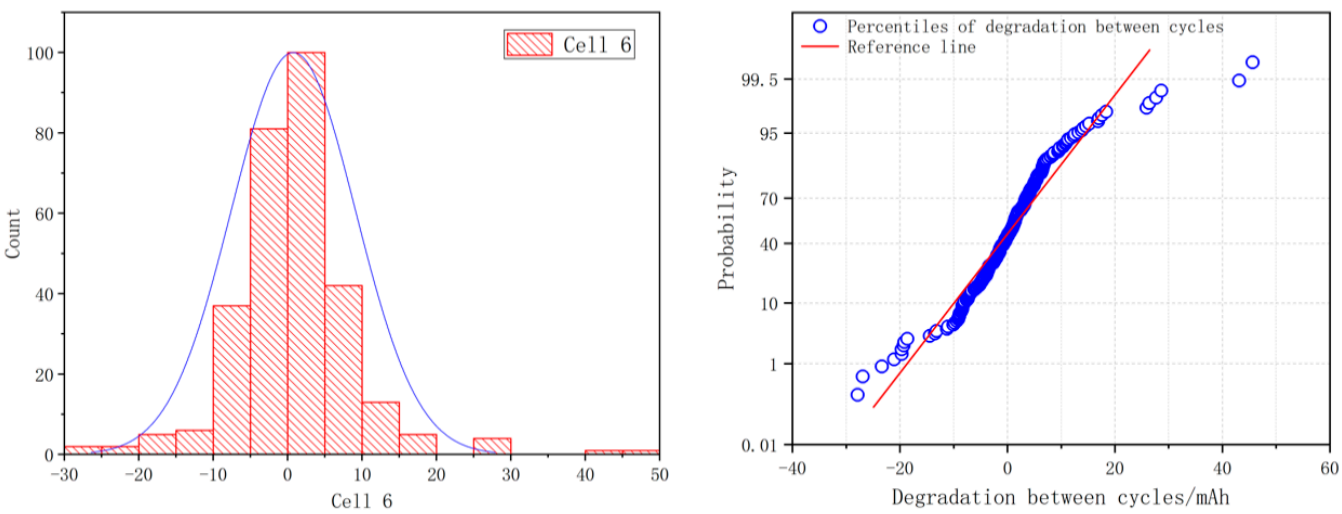

(b)
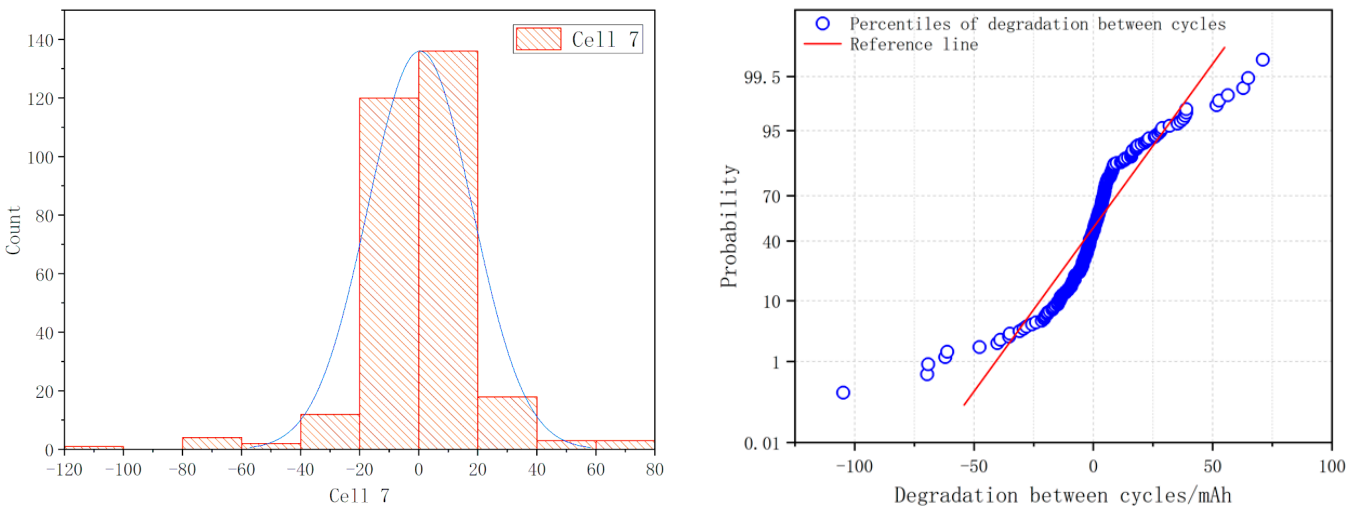

(c)
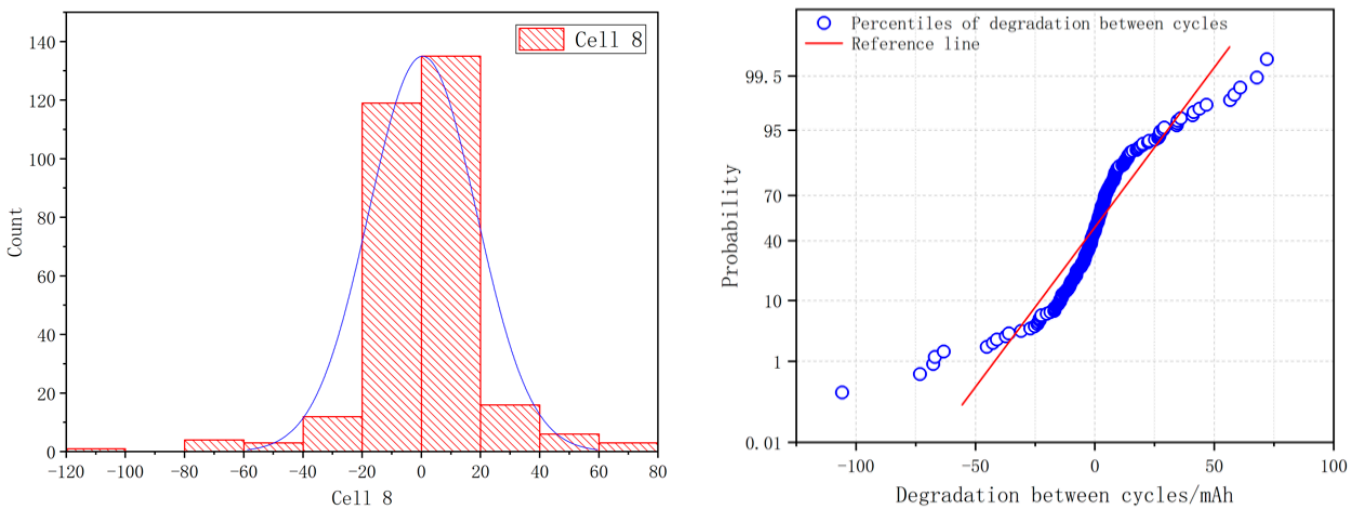

(d)

Figure A2. Cont. 

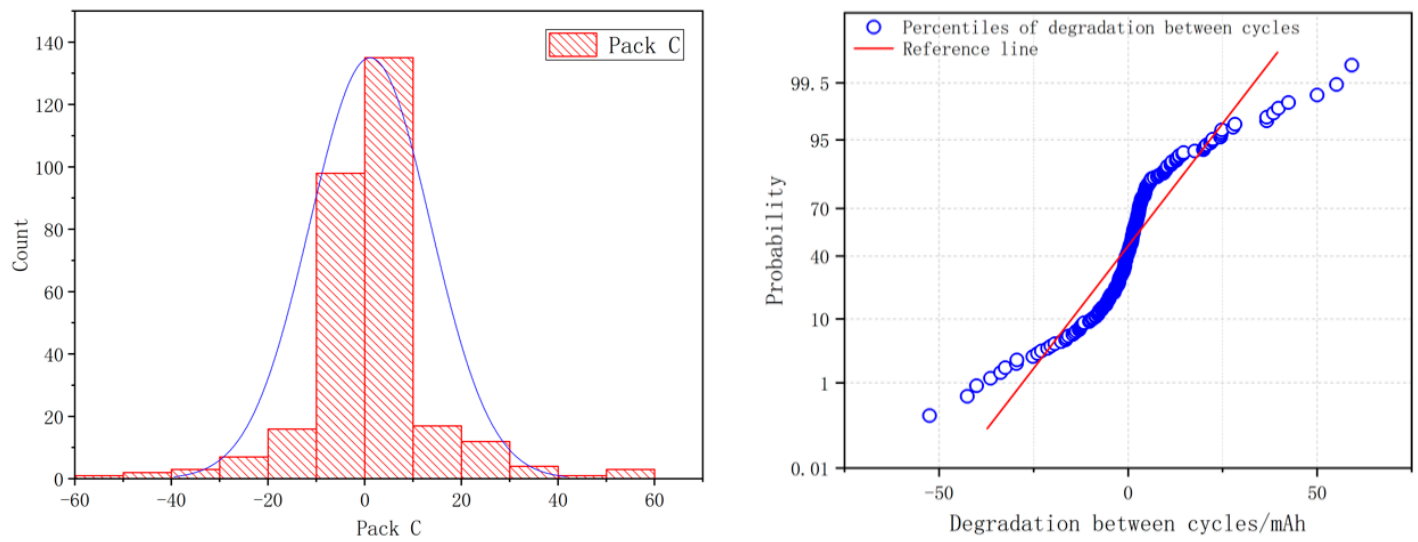

(e)

Figure A2. Probability map of capacity degradations between cycles: (a) Cell-5; (b) Cell-6; (c) Cell-7; (d) Cell-8; (e) Pack C.

\section{References}

1. Yun, L.; Sandoval, J.; Zhang, J.; Gao, L.; Garg, A.; Wang, C.T. Lithium-Ion Battery Packs Formation with Improved Electrochemical Performance for Electric Vehicles: Experimental and Clustering Analysis. J. Electrochem. Energy Convers. Storage 2019, 16, 11. [CrossRef]

2. Kim, K.; Park, K.; Lee, J.; Chun, K.; Lee, S.H. Analysis of Battery/Generator Hybrid Container Ship for $\mathrm{CO}_{2}$ Reduction. IEEE Access 2018, 6, 14537-14543. [CrossRef]

3. Donateo, T.; Ficarella, A.; Spedicato, L.; Arista, A.; Ferraro, M. A new approach to calculating endurance in electric flight and comparing fuel cells and batteries. Appl. Energy 2017, 187, 807-819. [CrossRef]

4. Wang, X.Y.; Zhao, X.; Wang, S.Q.; Sun, L.P. Reliability and maintenance for performance-balanced systems operating in a shock environment. Reliab. Eng. Syst. Saf. 2020, 195. [CrossRef]

5. Zhang, C.P.; Jiang, Y.; Jiang, J.C.; Cheng, G.; Diao, W.P.; Zhang, W.G. Study on battery pack consistency evolutions and equilibrium diagnosis for serial- connected lithium-ion batteries. Appl. Energy 2017, 207, 510-519. [CrossRef]

6. He, X.M.; Zhang, G.; Feng, X.N.; Wang, L.; Tian, G.Y.; Ouyang, M.G. A Facile Consistency Screening Approach to Select Cells with Better Performance Consistency for Commercial 18650 Lithium Ion Cells. Int. J. Electrochem. Sci. 2017, 12, 10239-10258. [CrossRef]

7. Sakti, A.; Azevedo, I.M.L.; Fuchs, E.R.H.; Michalek, J.J.; Gallagher, K.G.; Whitacre, J.F. Consistency and robustness of forecasting for emerging technologies: The case of $\mathrm{Li}$-ion batteries for electric vehicles. Energy Policy 2017, 106, 415-426. [CrossRef]

8. Rumpf, K.; Rheinfeld, A.; Schindler, M.; Keil, J.; Schua, T.; Jossen, A. Influence of Cell-to-Cell Variations on the Inhomogeneity of Lithium-Ion Battery Modules. J. Electrochem. Soc. 2018, 165, A2587-A2607. [CrossRef]

9. Santhanagopalan, S.; White, R.E. Quantifying Cell-to-Cell Variations in Lithium Ion Batteries. Int. J. Electrochem. 2012. [CrossRef]

10. Wang, X.; Wang, Z.; Wang, L.; Wang, Z.; Guo, H. Dependency analysis and degradation process-dependent modeling of lithium-ion battery packs. J. Power Sources 2019, 414, 318-326. [CrossRef]

11. Qi, J.; Lu, D.D.C. Review of Battery Cell Balancing Techniques. In Proceedings of the 2014 Australasian Universities Power Engineering Conference (AUPEC), Perth, Australia, 28 September-1 October 2014.

12. Cao, J.; Schofield, N.; Emadi, A. Battery balancing methods: A comprehensive review. In Proceedings of the 2008 IEEE Vehicle Power and Propulsion Conference, Harbin, China, 3-5 September 2008.

13. Omariba, Z.B.; Zhang, L.; Sun, D.J.I.A. Review of Battery Cell Balancing Methodologies for Optimizing Battery Pack Performance in Electric Vehicles. IEEE Access 2019, 7, 129335-129352. [CrossRef] 
14. Devie, A.; Baure, G.; Dubarry, M. Intrinsic Variability in the Degradation of a Batch of Commercial 18650 Lithium-Ion Cells. Energies 2018, 11, 31. [CrossRef]

15. Feng, X.N.; Xu, C.S.; He, X.M.; Wang, L.; Zhang, G.; Ouyang, M.G. Mechanisms for the evolution of cell variations within a LiNixCoyMnzO2/graphite lithium-ion battery pack caused by temperature non-uniformity. J. Clean Prod. 2018, 205, 447-462. [CrossRef]

16. Rumpf, K.; Naumann, M.; Jossen, A. Experimental investigation of parametric cell-to-cell variation and correlation based on 1100 commercial lithium-ion cells. J. Energy Storage 2017, 14, 224-243. [CrossRef]

17. Wang, Z.P.; Liu, P.; Wang, L.F. Analysis on the capacity degradation mechanism of a series lithium-ion power battery pack based on inconsistency of capacity. Chin. Phys. B 2013, 22. [CrossRef]

18. Li, J.Q.; Tan, F.; Zhang, C.N.; Sun, F.C. Capacity Fade Diagnosis of Lithium ion Battery Pack in Electric Vehicle Base on Fuzzy Neural Network. Energy Proced. 2014, 61, 2066-2070. [CrossRef]

19. Peterson, S.B.; Apt, J.; Whitacre, J.F. Lithium-ion battery cell degradation resulting from realistic vehicle and vehicle-to-grid utilization. J. Power Sources 2010, 195, 2385-2392. [CrossRef]

20. Stoican, O.S. Voltage Reversal in Series-connected Three 1.5V AAA Alkaline Batteries. Int. J. Electrochem. Sci. 2019, 14, 897-904. [CrossRef]

21. Aizpuru, I.; Iraola, U.; Canales, J.M.; Unamuno, E.; Gil, I. Battery pack tests to detect unbalancing effects in series connected Li-ion cells. In Proceedings of the 4th International Conference on Clean Electrical Power: Renewable Energy Resources Impact, ICCEP 2013, Alghero, Italy, 11-13 June 2013; pp. 99-106.

22. Chang, L.; Zhang, C.H.; Wang, T.X.; Yu, Z.H.; Cui, N.X.; Duan, B.; Wang, C.Y. Correlations of cell-to-cell parameter variations on current and state-of-charge distributions within parallel-connected lithium-ion cells. J. Power Sources 2019, 437. [CrossRef]

23. Baochang, S.; Aidi, S.J.C.M. Control. Modelling and Current Distribution of Parallel-connected Lithium Cells. Comput. Meas. Control 2017, 25. [CrossRef]

24. Zhang, Y.C.; Zhao, R.X.; Dubie, J.; Jahns, T.; Juang, L. Investigation of Current Sharing and Heat Dissipation in Parallel-Connected Lithium-Ion Battery Packs. In Proceedings of the 2016 IEEE Energy Conversion Congress and Exposition (ECCE), Milwaukee, WI, USA, 18-22 September 2016.

25. Feng, X.N.; Xu, C.S.; He, X.M.; Wang, L.; Gao, S.; Ouyang, M.G. A graphical model for evaluating the status of series-connected lithium-ion battery pack. Int. J. Energy Res. 2019, 43, 749-766. [CrossRef]

26. Ko, S.T.; Lee, J.; Ahn, J.H.; Lee, B.K. Innovative Modeling Approach for Li-Ion Battery Packs Considering Intrinsic Cell Unbalances and Packaging Elements. Energies 2019, 12, 356. [CrossRef]

27. Dubarry, M.; Pastor-Fernandez, C.; Baure, G.; Yu, T.F.; Widanage, W.D.; Marco, J. Battery energy storage system modeling: Investigation of intrinsic cell-to-cell variations. J. Energy Storage 2019, 23, 19-28. [CrossRef]

28. Dubarry, M.; Baure, G.; Pastor-Fernandez, C.; Yu, T.F.; Widanage, W.D.; Marco, J. Battery energy storage system modeling: A combined comprehensive approach. J. Energy Storage 2019, 21, 172-185. [CrossRef]

29. Hong, H.P.; Zhou, W.; Zhang, S.; Ye, W.J.R.E.; Safety, S. Optimal condition-based maintenance decisions for systems with dependent stochastic degradation of components. Reliab. Eng. Syst. Saf. 2014, 121, 276-288. [CrossRef]

30. D'Amico, G.; Petroni, F. Copula based multivariate semi-Markov models with applications in high-frequency finance. Eur. J. Oper. Res. 2018, 267, 765-777. [CrossRef]

31. Guven, G.; Samkar, H. Examination of Dimension Reduction Performances of PLSR and PCR Techniques in Data with Multicollinearity. Iran. J. Sci. Technol. Trans. A-Sci. 2019, 43, 969-978. [CrossRef]

32. Hannan, M.A.; Lipu, M.S.H.; Hussain, A.; Mohamed, A. A review of lithium-ion battery state of charge estimation and management system in electric vehicle applications: Challenges and recommendations. Renew. Sustain. Energy Rev. 2017, 78, 834-854. [CrossRef]

33. Yedluri, A.K.; Anitha, T.; Kim, H.J. Fabrication of Hierarchical NiMoO4/NiMoO4 Nanoflowers on Highly Conductive Flexible Nickel Foam Substrate as a Capacitive Electrode Material for Supercapacitors with Enhanced Electrochemical Performance. Energies 2019, 12, 1143. [CrossRef]

34. Kumar, Y.A.; Kumar, K.D.; Kim, H.J. Reagents assisted ZnCo2O4 nanomaterial for supercapacitor application. Electrochim. Acta 2020, 330. [CrossRef] 
35. Mu, Y.S.; Liu, X.D.; Wang, L.D. A Pearson's correlation coefficient based decision tree and its parallel implementation. Inf. Sci. 2018, 435, 40-58. [CrossRef]

36. Brozek, K.; Kogut, J. Analysis of pearson's linear correlation coefficient with the use of numerical examples; Melandrium: Slany. In Proceedings of the 10th International Days of Statistics and Economics, Prague, Czech Republic, 8-10 September 2016; 2016; pp. 247-255.

Publisher's Note: MDPI stays neutral with regard to jurisdictional claims in published maps and institutional affiliations.

(C) 2020 by the authors. Licensee MDPI, Basel, Switzerland. This article is an open access article distributed under the terms and conditions of the Creative Commons Attribution (CC BY) license (http://creativecommons.org/licenses/by/4.0/). 